\title{
A physiological production model for cocoa (Theobroma cacao): model presentation, validation and application
}

\author{
Pieter A. Zuidema ${ }^{a, b, *}$, Peter A. Leffelaar ${ }^{a}$, \\ Wouter Gerritsma $^{\text {a, } 1}$, Liesje Mommer ${ }^{\text {a,c }}$, Niels P.R. Anten ${ }^{\text {a,b }}$ \\ a Plant Production Systems Group, Wageningen University, PO Box 430, \\ 6700 AK Wageningen, The Netherlands \\ ${ }^{\mathrm{b}}$ Department of Plant Ecology, Utrecht University, PO Box 80084, 3508 TB Utrecht, The Netherlands \\ ${ }^{\mathrm{c}}$ Department of Experimental Plant Ecology, University of Nijmegen, PO Box 9010, \\ 6500 GL Nijmegen, The Netherlands
}

Received 6 January 2004; received in revised form 4 June 2004; accepted 22 June 2004

\begin{abstract}
In spite of the economic importance and extensive agronomic literature on cocoa, no physiological production model has been developed for cocoa so far. Such a model would be very useful to compare yields in different climates and cropping systems, and to set the agenda for future agronomic research. Here, we present and apply such a physiological growth and production model for cocoa (SUCROS-Cocoa), based on the SUCROS-family of physiological crop growth models. Our model calculates light interception, photosynthesis, maintenance respiration, evapotranspiration, biomass production and bean yield for cocoa trees grown under shade trees. It can cope with both potential and water-limited situations, and is parameterised using existing information on cocoa physiology and morphology. A validation study showed that the model produces realistic output for bean yield, standing biomass, leaf area and
\end{abstract}

\footnotetext{
${ }^{*}$ Corresponding author. Tel.: +31 302536 835; fax: +31 302518366.

E-mail address: p.a.zuidema@bio.uu.nl (P.A. Zuidema).

${ }^{1}$ Present address: Library, Wageningen University, PO Box 9600, 6700 HA Wageningen, The
} Netherlands. 
size-age relations. Simulations were carried out using climatic information of 30 locations in 10 cocoa-producing countries, three different soil types and varying shade levels.

The model was applied to answer four questions that are currently relevant to cocoa production. (1) Which are the most important yield-determining parameters? Sensitivity analyses revealed that these parameters were chiefly related to the morphology of fruits, photosynthesis and maintenance respiration. (2) To what extent can cocoa yield be predicted by rainfall and irradiance data? Regression analyses showed that over $70 \%$ of the variation in simulated bean yield could be explained by a combination of annual radiation and rainfall during the two driest months. (3) How large is the cocoa yield gap due to water limitation? Yield gaps were large - up to $50 \%$ - for locations with a strong dry season combined with an unfavourable (clayey or sandy) soil. The calculated yield gaps decreased exponentially with the amount of rain during the two driest months. (4) What are the consequences of shading on cocoa yield? Our simulations showed that moderate shade levels hardly affected bean yield, whereas heavy shading $(>60 \%)$ reduced yields by more than one-third.

(c) 2004 Elsevier Ltd. All rights reserved.

Keywords: Crop production; Cocoa; Cacao; Theobroma cacao; Simulation models; SUCROS

\section{Introduction}

Physiological growth and production models have shown to be very useful for guiding improvements in cropping systems of various annual crops (e.g., wheat, rice, potatoes; Van Laar et al., 1997; Bouman et al., 2001; Wolf, 2002). Such simulation models have been constructed for a large number of short-lived crops (e.g., Marcelis et al., 1998; Van Ittersum and Donatelli, 2003; Van Ittersum et al., 2003). They provide insight in the functioning of cropping systems, by applying a system's approach (De Wit et al., 1978; Leffelaar, 1999). For perennial crops much less work on production models has been carried out (Cannell, 1985; Van Kraalingen et al., 1989; Mohren et al., 1984; Wagemakers, 1995), probably due to data limitation, relatively high research costs and the difficulties of accumulated errors in long-term simulations.

Cocoa (Theobroma cacao) is one of the most important perennial crops worldwide, with an estimated world production of 2.8 million tons in 2002 (FAO, 2003). Although the body of cocoa research is very large (e.g., Ahenkorah et al., 1974; Alvim, 1977; Wood and Lass, 1985; Somarriba et al., 2001), the results of cocoa studies have never been integrated into a physiological production model. The cocoa production models that have been established so far are either regressionbased models with limited applicability for locations other than the ones for which data were collected (e.g., Fassbender et al., 1991; Beer et al., 1990), or are conceptual models which are not suitable for yield simulations (e.g., Hutcheon, 1976; Alvim, 1977; Balashima, 1991; Yapp and Hadley, 1994 but see Ng, 1982). For cocoa, physiological simulation models may be valuable to compare attainable cocoa production between locations, soil types and cropping systems, to obtain insight in the main factors determining yield and to identify gaps in knowledge on cocoa production. 
In this paper, we present a physiological growth and yield model for cocoa (SUCROS-Cocoa), which is based on the standard SUCROS model (Van Ittersum et al., 2003) to which substantial adaptations were made to allow for modelling of perennial growth and typical aspects of fruit ripening and evapotranspiration of cocoa trees. This model was constructed to integrate and exploit existing knowledge on the physiology and agronomy of cocoa trees in plantations, and to identify gaps in knowledge on cocoa growth and yield. To our knowledge, this is the first physiological growth and production model for cocoa. It is a 'generic' model as it uses general physiological relations and has been parameterised with information that is not specific to one location, one cocoa variety or hybrid, or one cropping system. This also implies that it is not targeted at predicting cocoa yield for a specific combination of a certain variety, cropping system and location, but that it is rather meant for general comparisons of cocoa yield in different climates and cropping systems.

After presenting the model, we show how the model can be applied to address some questions relevant to cocoa production: (1) What are the most important parameters determining cocoa yield?; (2) To what extent can rainfall and irradiance data predict cocoa production?; (3) How large is the cocoa yield gap due to water limitation and how does this depend on climate and soil characteristics?; and (4) What are the consequences of shading on cocoa yield? The first question is addressed in a sensitivity analysis, the others in various scenario studies, using climatic data of 30 locations in cocoa growing areas throughout the Tropics.

\section{Methods}

\subsection{Model}

The SUCROS-Cocoa model is a physiological simulation model for cocoa that calculates growth and production of cocoa plantations, with or without water limitation. SUCROS-Cocoa is largely based on the SUCROS (Van Laar et al., 1997) and INTERCOM (Kropff and Van Laar, 1993) models. SUCROS models are physiological crop growth simulation models that calculate leaf-based light interception and photosynthesis, maintenance respiration, biomass growth and crop production in time, and have been applied mainly for annual crops. The INTERCOM model is derived from SUCROS and produces similar output, but for situations with several competing species: multiple crops, crops and weeds, crops and shade trees. For theoretical background on these models we refer to their original documentation (Van Laar et al., 1992, 1997; Kropff and Van Laar, 1993; Goudriaan and Van Laar, 1994 and a review in Van Ittersum et al., 2003). For a full documentation of the SUCROS-Cocoa (previously presented as "CASE2", version 2.2), see the technical program manual (Zuidema et al., 2003; earlier versions are described in Anten et al., 1993; Gerritsma and Wessel, 1999). Here we describe only those components of our model that differ from the standard INTERCOM and SUCROS approaches. 


\subsubsection{Model tree}

The cocoa model tree consist of five different organs: leaves, wood, lateral roots, a taproot and fruits (or pods; Fig. 1). Lateral roots are subdivided into fine lateral roots $(<2 \mathrm{~mm}$ diameter) which are able to extract water, and coarser roots. In the model, fine lateral roots are characterised by their biomass and have a certain vertical distribution in the soil. Leaves are characterised by their biomass, their area (calculated using the specific leaf area, SLA) and a certain vertical distribution. The remaining organs are characterised only by their biomass, not by their extent or position in space. Shade trees are represented in the model by a leaf layer only, which is characterised by a leaf area index (LAI) and a lower and upper canopy boundary.

\subsubsection{Rainfall interception, evapotranspiration and water balance}

Part of the daily rainfall is intercepted by the canopy and then evaporates. The remaining portion reaches the soil by through-fall (Boyer, 1970) and is the input
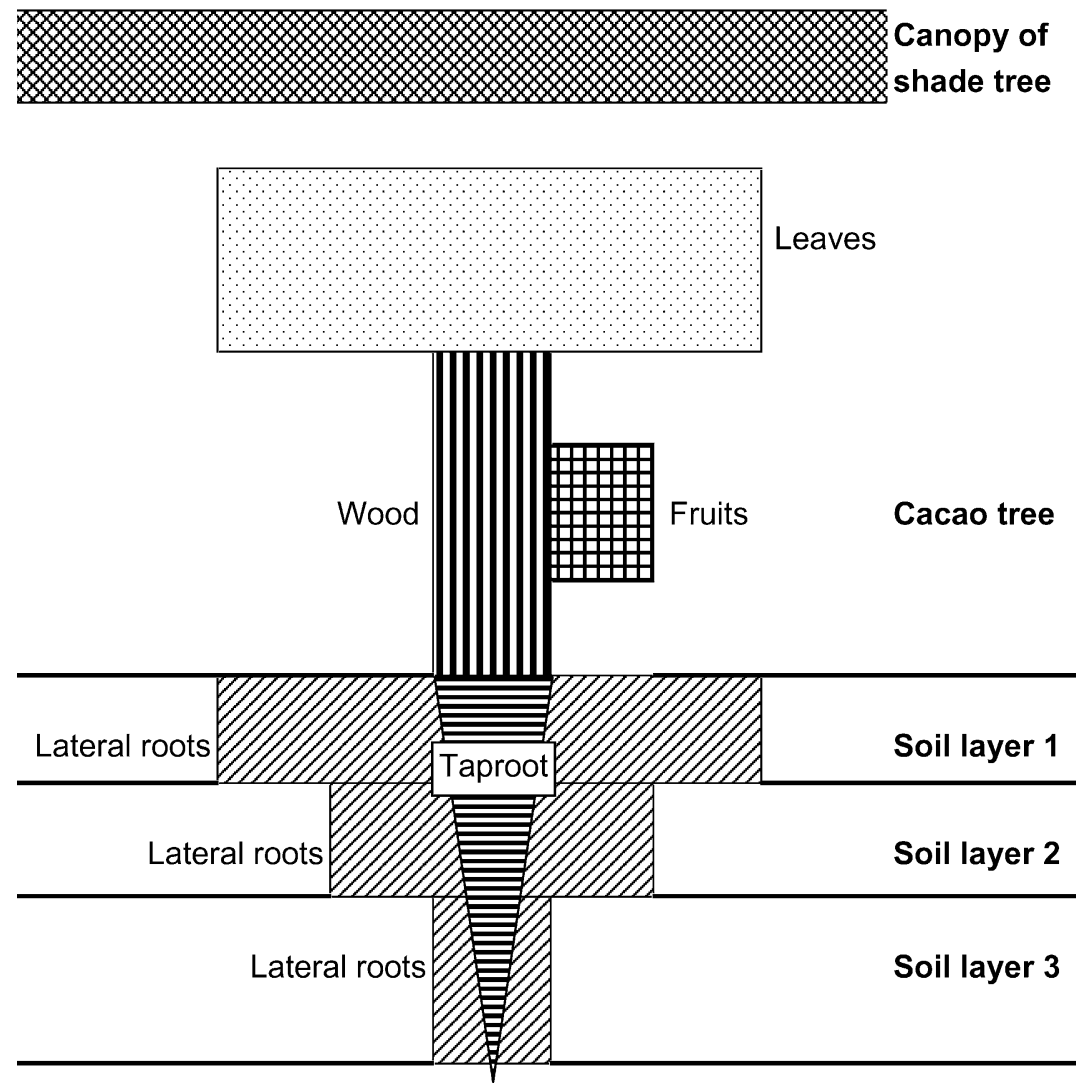

Fig. 1. Representation of the organs of the model cacao tree and shade tree in the SUCROS-Cocoa model. See text for explanation. As the model assumes a homogeneous and closed canopy of cacao trees, the neighbouring model trees border directly to the canopy of the depicted tree. 
of water into the first soil layer. The soil consists of a number of layers, each characterised by a thickness and a water retention curve. The temporal changes in water content of the soil layers is described in a water balance model as in SUCROS2 and SUCROS97 (Van Keulen, 1975; Van Keulen and Seligman, 1987; Van Laar et al., 1997 see also Van den Berg et al., 2002). The water content in each soil layer may fluctuate between wilting point $(p \mathrm{~F}=4.2)$ and field capacity $(p \mathrm{~F}=2.0)$. The processes included in this water balance are infiltration, water uptake by roots (by evapotranspiration of cacao trees), downward redistribution of water and external drainage, following the 'tipping bucket' principle (Van Keulen, 1975; Van Ittersum et al., 2003). Evaporation from the soil surface is assumed to be negligible in multi-layer tree plantations in which little sunlight reaches the soil. The water balance model redistributes the water among the soil layers within one day, which means that field capacity is assumed to be reached in one day. Water uptake by roots is modelled in a slightly different way than in SUCROS. Uptake depends on the fine root surface, the amount of water in a soil layer and the amount of water required for evapotranspiration. The biomass of fine roots in soil layer $i\left(W_{\mathrm{fr}, i} ; \mathrm{kg}\right)$ is converted to root length $l_{i}(\mathrm{~m})$ as $l_{i}=W_{\mathrm{fr}, i} \times$ slr, with slr being the specific root length $\left(\mathrm{m} \mathrm{kg}^{-1}\right)$. Root length is then converted to area $A_{i}\left(\mathrm{~m}^{2}\right)$ as: $A_{i}=2 \pi \times r \times l_{i}$, in which $r$ is the average radius of the roots $(\mathrm{m})$. The sum of the root surface in all soil layers $\left(A_{\mathrm{tot}}, \mathrm{m}^{2}\right)$ is used to determine the potential water extraction per unit root surface (in $\mathrm{mm} \mathrm{d}^{-1} \mathrm{~m}^{-2}$ ): $\mathrm{WU}_{\text {pot }}=\mathrm{ET}_{p} / A_{\text {tot }}$, in which $\mathrm{ET}_{p}$ is the potential evapotranspiration $\left(\mathrm{mm} \mathrm{d}^{-1}\right) . \mathrm{A}$ maximum rate of water uptake per soil layer $\left(\mathrm{WU}_{i, \max }, \mathrm{mm} \mathrm{d}^{-1}\right)$ is calculated based on the root surface $\left(A_{i}, \mathrm{~m}^{2}\right)$, the potential water extraction rate $\left(\mathrm{WU}_{\mathrm{pot}}, \mathrm{mm} \mathrm{d}^{-1}\right)$ and a drought factor $\left(f_{\text {drought }}\right): \mathrm{WU}_{i, \max }=A_{i} \times f_{\text {drought }} \times \mathrm{WU}_{\text {pot }}$. The drought factor $f_{\text {drought }}$ (dimensionless) is a water uptake reduction factor that accounts for the difficulty of water extraction at low water availability. $f_{\text {drought }}$ equals 1 if water content in soil layer $i$ is above a certain critical water content, 0 if it is below wilting point and has a value between 0 and 1 if water content is between wilting point and critical water content. The critical water content is a value between wilting point and field capacity at which water extraction is affected by limiting water availability, and is calculated using the potential transpiration and a crop-characteristic transpiration rate (see Zuidema et al., 2003 for details). The realised water uptake equals the potential if sufficient water is available in the soil layer; if not, it equals the available amount. The amount of available water in soil layer $i\left(\mathrm{WC}_{i, \text { avail }}, \mathrm{mm}\right)$ is calculated as: $\mathrm{WC}_{i \text {,avail }}=\left(\mathrm{WC}_{\text {field }}-\mathrm{WC}_{\text {wilting }}\right) \times \Delta d_{i}$, in which $\mathrm{WC}_{\text {field }}$ is the volumetric water content of the soil type of layer $i$ at field capacity $\left(\mathrm{mm} \mathrm{H}_{2} \mathrm{O}\right.$ per $\mathrm{mm}$ of soil) and $\mathrm{WC}_{\text {wilting }}$ is that at wilting point, and $\Delta d_{i}$ is the thickness of the soil layer (mm).

The actual evapotranspiration rate $\left(\mathrm{ET}_{a}\right)$ is equal to the potential rate $\left(\mathrm{ET}_{p}\right)$ in case sufficient water can be extracted from the soil, or to the available amount of water when this is not the case. Potential evapotranspiration $\left(\mathrm{ET}_{p}\right)$ is calculated using the Penman-Monteith combination equation (Van Kraalingen and Stol, 1997; as adapted in Wallace, 1996), modified for the use of cacao. The aerodynamic resistance $\left(r_{\mathrm{a}}\right)$ was obtained from literature $\left(38 \mathrm{~s} \mathrm{~m}^{-1}\right.$, Radersma and De Ridder, 1996) as no wind function has been defined for tree crops. The surface resistance of the canopy $\left(r_{\mathrm{c}}\right)$ was calculated using the simple approach of Kelliher et al. 
(1995) for non-stressed crops with LAI > 3.5: $r_{\mathrm{c}}=r_{1} / 3$, where $r_{1}$ is the minimum leaf resistance $\left(r_{1}=150 \mathrm{~s} \mathrm{~m}^{-1}\right.$; Radersma and De Ridder, 1996). The water availability factor $\varphi$ is equal to $\mathrm{ET}_{\mathrm{a}} / \mathrm{ET}_{\mathrm{p}}$.

\subsubsection{Light interception and photosynthesis}

Light interception and competition between cacao and shade trees is modelled as in the INTERCOM model, with exponential light extinction as a function of leaf area, separation of direct and indirect light fluxes and interception depending on leaf orientation. Photosynthesis and further growth processes in SUCROS-Cocoa are based on SUCROS and are calculated for cacao trees (not for shade trees). The rate of photosynthesis of individual leaves is calculated using the light-saturated photosynthesis rate $\left(A_{\max }\right)$, the initial slope of the photosynthesis-light curve and the amount of absorbed light. Leaf photosynthesis rates at various times of the day and in various layers of the canopy are integrated over time and canopy depth to obtain the canopy photosynthesis on a daily basis. The total daily production of carbohydrates by photosynthesis of the cacao canopy is multiplied by the water availability factor $(\varphi)$ to account for the closure of stomata during periods of water stress (cf. Alvim, 1960).

\subsubsection{Maintenance, biomass replacement and net organ growth respiration}

The simulated amount of carbohydrates produced by photosynthesis are used for maintenance respiration. The remaining carbohydrates are stored as 'reserves' and partitioned over the different organs (Fig. 2). Maintenance respiration is modelled as in SUCROS (Penning de Vries and Van Laar, 1982; Van Laar et al., 1997), depending on plant dry weight, protein and mineral content of the tissue and temperature (De Wit et al., 1978).

The carbohydrates that remain in the reserve pool after maintenance respiration are partitioned according to the total biomass of the model tree, and not on the basis of age, as in standard SUCROS models. For annual crops, the course of the development from small vegetative to large generative plants is closely related to plant physiological age. In contrast, for tree crops, such as cocoa, such relations are often weak, as small differences in growth rates of even-aged trees accumulate over long periods of time, finally leading to large differences in total biomass after several decades. For cocoa, which is grown under widely fluctuating light conditions such differences may be especially large. Therefore, in SUCROS-Cocoa the partitioning of available reserves is based on the size of the model tree (expressed in biomass). For this partitioning, allometric relations between the organ biomass and total biomass are used (Fig. 3), which are usually very strong in trees (Niklas and Enquist, 2002). Although the slope of these allometric relations show the increase in organ biomass with increasing total biomass, they cannot be directly translated into partitioning rules. These relations do not include turnover of (parts of) certain organs such as leaf dynamics, fruit harvesting and root turnover. As the rate of turnover differs between plant organs, the replacement of lost biomass should first be taken into account in the carbohydrate partitioning before organs can start to grow according to the allometric relations. Thus, in SUCROS-Cocoa, partitioning of carbohydrates 


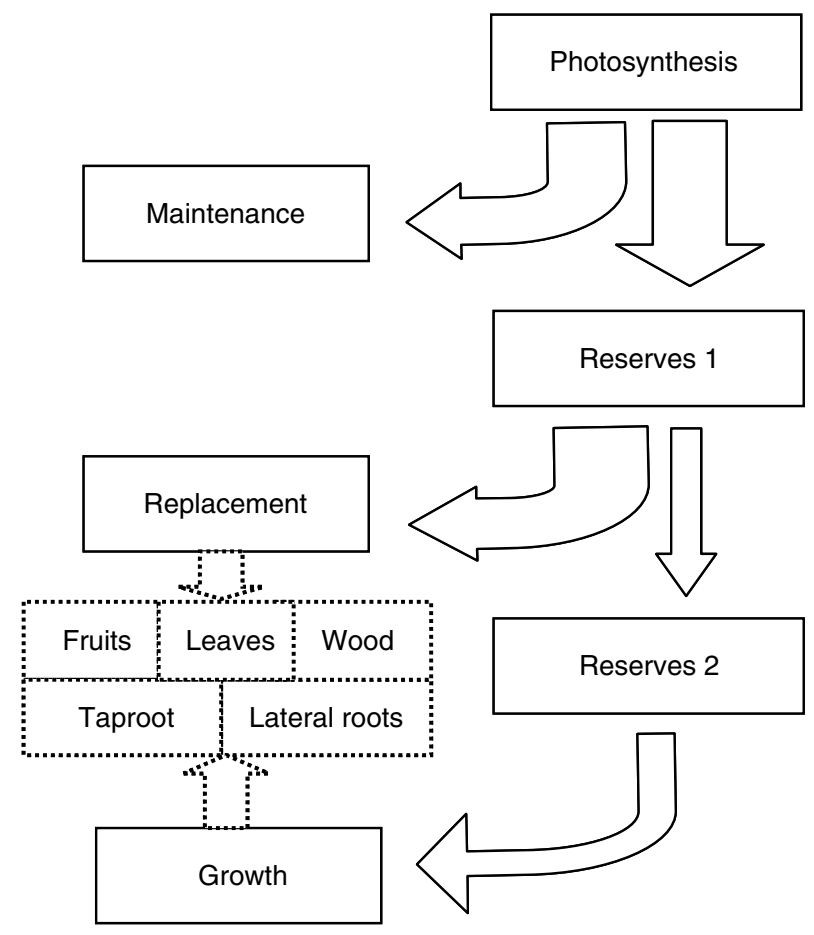

Fig. 2. Flow diagram showing the three-step approach to partition carbohydrates as used in the SUCROS-Cocoa model. Boxes with drawn borders denote amounts of carbohydrates; those with dotted borders denote amounts of biomass. Drawn arrows are fluxes of carbohydrates; dotted arrows represent conversions from carbohydrates to biomass.

is divided in two parts (Fig. 2): the first part being the replacement of lost biomass, and the second the net growth in biomass of organs.

In the first part of the carbohydrate partitioning, the daily amount of biomass lost due to turnover is calculated for each organ and the available reserves are first used to replace this lost biomass. For fine roots ( $<2 \mathrm{~mm}$ diameter), lost biomass is calculated as: $\mathrm{d} W_{\text {lost }} / \mathrm{d} t=R_{\text {turnover }} \times W$, in which $\mathrm{d} W_{\text {lost }} / \mathrm{d} t$ is the daily loss rate of dry weight $\left(\mathrm{kg} \mathrm{d}^{-1}\right), R_{\text {turnover }}$ is the relative turnover rate $\left(\mathrm{d}^{-1}\right)$ and $W$ is the fine root dry weight. For leaves and fruits $\mathrm{d} W_{\text {lost }} / \mathrm{d} t$ is calculated as the average dry weight loss over the 10 preceding days in the simulation. For leaves, this rate depends on the leaf life time and on water stress (see Section 2.1.5). For fruits, lost biomass equals the dry weight of ripe fruits which depends on investment in fruits during the preceding months (see Section 2.1.5). For wood and coarse lateral roots, the turnover rate is calculated as a fraction of the loss of leaves and fine lateral roots, respectively, as no estimates for relative turnover rates were available for cacao (cf. Veneklaas and Poorter, 1998). The costs for replacement of lost biomass are covered by the reserve pool and are calculated for each organ as the product of the lost biomass and the assimilation requirement $(G)$ for the production of $1 \mathrm{~kg}$ dry weight of that organ. 
(a)

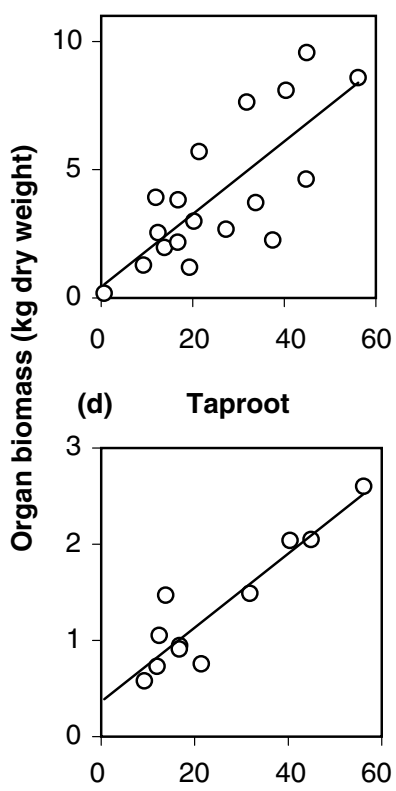

(b) Stem + branch

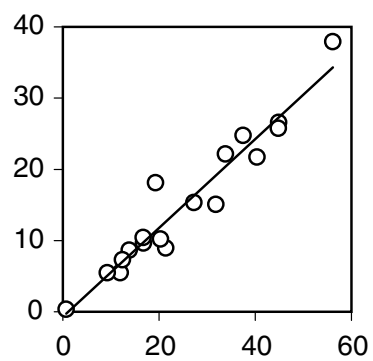

(e) Fruits

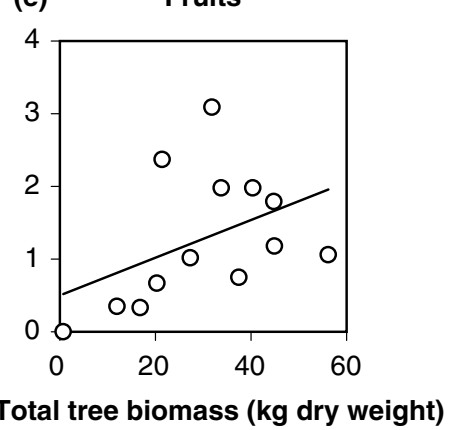

(c) Lateral roots

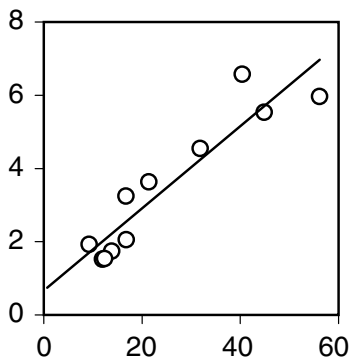

Fig. 3. Relations between weight of different organs and total weight of cacao trees in different plantations and countries. Circles denote individuals trees (or the average value for several trees), as reported in the sources; drawn lines are linear regression lines through the data points. The measured cacao trees were grown in different shading environments in six countries: Brazil, Congo, Costa Rica, Malaysia, Nigeria and Venezuela. Linear regressions explained 58\% (a), 93\% (b), 85\% (c), 87\% (d) and 19\% (e) of the variation in organ weight. Data sources: Van Himme, 1959; Thong and Ng, 1980; Aranguren et al., 1982; Alpizar et al., 1986; Teoh et al., 1986; Beer et al., 1990; Opanukle, 1991; Subler, 1994.

In the second part of the carbohydrate partitioning, the allometric relations between organ biomass and total biomass are used. The distribution of assimilates over the different organs depends on several factors: the actual proportions of biomass in the organs $\left(p_{\text {act }}\right)$, the "ideal" proportion of biomass in the organs following the allometric relations $\left(p_{\text {ideal }}\right)$, the slope of the allometric function $\left(a_{\text {allo }}\right)$ and the availability of water $(\varphi)$. The ideal proportion of biomass in leaves and fine lateral roots is modified by the water availability factor $(\varphi)$ to account for changed partitioning to these organs in case of water stress (cf. Alvim and Alvim, 1977). For leaves, the $p_{\text {ideal }}$ is obtained by multiplying the fraction taken from the allometric relation by $\varphi$; for fine roots by multiplying by $(2-\varphi)$. Then, for each organ, the ideal and actual proportions are compared. If the actual proportion is higher than or equal to the ideal proportion, the fraction of carbohydrates partitioned to this organ is zero. If it is lower, part of the available reserves is allocated to the organ. The partitioning fraction is calculated as: $f=a_{\text {allo }} \times\left(p_{\text {ideal }}-p_{\text {act }}\right) / p_{\text {act }}$, in which $f$ is the fraction of carbohydrates partitioned to a certain organ (dimensionless, within a minimum value of 
zero) and $a_{\text {allo }}$ is the slope of the allometric regression line. Using the calculated partitioning fractions and the assimilate requirements to produce a unit of biomass of each organ, the total amount of assimilates to produce one $\mathrm{kg}$ of new tissue is calculated as in SUCROS. The amount of assimilates in the reserve pool determines the total biomass growth.

\subsubsection{Leaf and fruit dynamics}

Dynamics of leaves and fruits are modelled in escalator boxcar trains (Goudriaan and Van Roermund, 1999). Leaves of a certain age (in days) are stored in a leaf age class (boxcar). Leaves move to the next after each simulation day. New leaves are included in the first class and are produced continuously. Leaves are thus not produced in flushes as in real cacao trees. Leaf production depends on the amount of leaf loss, on the allometric relation for leaves and on the water availability $(\varphi)$. Leaf shedding occurs when leaves have reached the maximum age and due to drought. Low water availability (low $\varphi$ ) causes additional leaf loss as: $\mathrm{d} W_{\text {lost }} / t=D_{\text {water }} \times W_{\mathrm{L}}$ in which $\mathrm{d} W_{\text {lost }} / t$ is the daily weight of lost leaves due to drought $\left(\mathrm{kg} \mathrm{d}^{-1}\right), D_{\text {water }}$ is the relative death rate of leaves due to drought $\left(\mathrm{d}^{-1}\right)$ and $W_{\mathrm{L}}$ is the leaf weight. $D_{\text {water }}$ is calculated as: $D_{\text {water }}=1 / L_{\text {adj }}-1 / L_{\text {max }}$ in which $L_{\text {adj }}$ is the adjusted leaf life span and $L_{\max }$ is the leaf age under optimal water availability. The adjusted leaf life span is calculated as: $L_{\mathrm{adj}}=(1-\varphi) \times L_{\min }+\varphi \times L_{\max }$, in which $L_{\min }$ is the leaf life span under severe water stress.

As for leaves, growth and development of fruits is modelled by means of a boxcar train. Fruits are divided into age classes (boxcars), and the total number of classes equals the fruit ripening period. When fruits are ripe, they are harvested and their biomass is removed from the total fruit biomass. The rate of fruit ripening depends on the average temperature, following a near-linear and positive relation (Hadley et al., 1994). Fruits in each class have a ripening status between 0 (pollinated flowers) and 1 (ripe fruits). The ripening status of fruits is changed each simulation day, depending on the average temperature. Fruits in classes with ripening status of 1 are "harvested" in the model. The fruit weight in that class is the daily harvest. Biomass invested in fruits is used for growth of existing fruits and for producing new fruits. New fruits are included in the first age class. Available biomass for fruit production is distributed over the age classes using a distribution parameter, the sink strength (the strength with which fruit classes 'pull' the resources): $\mathrm{d} W_{i} / t=s_{i} /$ $s_{\text {sum }} \times \mathrm{d} W_{\text {all }} / t$, in which $\mathrm{d} W_{i} / t$ is the growth rate of fruits in class $i\left(\mathrm{~kg} \mathrm{~d}^{-1}\right) s_{i}$ is the sink strength of class $i$ (dimensionless), $s_{\text {sum }}$ is the sum of sink strength of all categories (dimensionless), $\mathrm{d} W_{\text {all }} / t$ is the increment in biomass of all fruits classes $(\mathrm{kg}$ $\mathrm{d}^{-1}$ ). In contrast to real cacao trees, trees in SUCROS-Cocoa produce new fruits every day, following a similar procedure as for leaf development. The weight of new fruits, though, varies periodically depending on the production of carbohydrates through photosynthesis.

\subsubsection{Commercial bean yield}

Daily harvest of fruits in the model is converted into commercial bean yield as $Y_{\mathrm{b}}=f_{\mathrm{b}} \times f_{\text {ferm }} \times\left(1+c_{\text {moist }}\right) \times Y_{\mathrm{f}}$, in which $Y_{\mathrm{b}}$ is the commercial bean yield $\left(\mathrm{kg} \mathrm{d}^{-1}\right.$; 
slightly wet), $f_{\mathrm{b}}$ is the weight fraction of beans in a fruit ( $\mathrm{kg}$ beans ( $\mathrm{kg}$ fruits $\left.)^{-1}\right), f_{\text {ferm }}$ is the fraction of bean weight present after fermentation (dimensionless), $c_{\text {moist }}$ is the moisture content of dry beans (dimensionless), and $Y_{\mathrm{f}}$ is the dry weight of harvested fruits $\left(\mathrm{kg} \mathrm{d}^{-1}\right)$. The fermentation fraction $f_{\text {ferm }}$ is calculated as: $f_{\text {ferm }}=a \times t_{\text {ferm }}+\mathrm{b}$ (Humphries, 1944), in which $a\left(\mathrm{~d}^{-1}\right.$, negative) and $b$ (dimensionless) are regression coefficients and $t_{\text {ferm }}$ is the fermentation duration (d).

\subsection{Model parameterisation}

SUCROS-Cocoa uses ca. 85 parameters on morphology and physiology of cacao trees. The values for these parameters were obtained from literature sources and can be found in Zuidema et al. (2003). SUCROS-Cocoa also uses weather and soil data and information on the cropping system.

\subsubsection{Model tree}

The allometric relations shown in Fig. 3 were used to derive organ weights from the total tree biomass. These relations were established for all five organs distinguished in SUCROS-Cocoa, and were rather strong despite the fact that data were collected in very different climates and cropping systems. The same data were used to relate tree age and biomass (see regression of observed values in Fig. $5(\mathrm{f}))$.

The following specific calculations were used to derive root parameters. Taproot length was calculated by assuming a cone-like shape (volume $=1 / 3 \times$ base $\times$ height), and a relation between root length and radius of 20:1. The following formula was used: $l_{\text {tap }}=\left[\left(W_{\text {tap }} \times 1200\right) /(s w \times \pi)\right]^{(1 / 3)}$, in which $l_{\text {tap }}$ is the taproot length $(\mathrm{m}), W_{\text {tap }}$ is the weight of the taproot $(\mathrm{kg}), s w$ is the specific weight of wood $\left(\mathrm{kg} \mathrm{m}^{-3}\right)$ of the cacao tree which is used to convert the cone weight to a volume and 1200 is a factor to account for the relation between root length and radius including the $1 / 3$ of the volume calculation of a cone. Fine lateral roots $(20 \%$ of the lateral root biomass, Kummerow et al., 1981) are distributed vertically over the different soil layers, applying an exponential decline of root weight over soil depth (Kummerow et al., 1981, 1982). Two categories of fine roots are distinguished: with a diameter of $<1$ and 1-2 $\mathrm{mm}$, each with an equal share in the total fine root biomass (Kummerow et al., 1981). Relative turnover rate of fine roots $\left(R_{\text {turnover }}\right)$ was taken from Muñoz and Beer (2001).

Specific leaf area (SLA, area leaf per unit leaf weight) was found to be linearly and positively related to total tree biomass (Thong and $\mathrm{Ng}, 1980$ ) and non-linearly and negatively to light availability (Guers, 1971).

\subsubsection{Light interception, photosynthesis and maintenance respiration}

Light extinction coefficients $(k)$ were taken as 0.6 for leaves and 0.5 for trunk (Boyer, 1971; Alvim, 1977; Wills and Yegappan, 1981; Yapp and Hadley, 1994). The maximum photosynthetic rate at light saturation $\left(A_{\max }\right)$ was taken as the highest rate found in studies on cacao trees $\left(16.0 \mathrm{~kg} \mathrm{CO}_{2}\right.$ (ha leaf) ${ }^{-1} \mathrm{~h}^{-1}$, Miyaji et al., 
Table 1

Data used to calculate coefficients for maintenance respiration $(M)$ and growth respiration $(G)$ of the SUCROS-Cocoa model

\begin{tabular}{|c|c|c|c|c|c|c|c|c|c|c|}
\hline \multirow[t]{2}{*}{ Plant organ } & \multicolumn{3}{|c|}{ Maintenance respiration } & \multicolumn{7}{|c|}{ Growth respiration } \\
\hline & $\mathrm{N}$ & Minerals & $M^{\mathrm{a}}$ & Carbohydrates & Protein & Lipids & Lignin & Organic acids & Minerals & $G^{\mathrm{b}}$ \\
\hline Leaves & 1.91 & 2.7 & 6.9 & 53 & 25 & 5 & 5 & 6 & 6 & 1.656 \\
\hline Wood & 0.43 & 1.8 & 2.4 & 49 & 2 & 1 & 38 & 5 & 5 & 1.569 \\
\hline Roots & 1.08 & 2.5 & 4.7 & 57 & 2 & 1 & 30 & 5 & 5 & 1.494 \\
\hline Fruits & 3.62 & 8.7 & 16 & 59 & 13 & 18 & 5 & 5 & 5 & 1.756 \\
\hline
\end{tabular}

Sources for M: Boyer, 1973; Santana and Cabala-Rosand, 1982; Thong and Ng, 1980; Alpizar et al., 1986. Sources for G: Teoh et al., 1986; Valle et al., 1990, for fruits; Goudriaan and Van Laar, 1994, for general values of other organs.

${ }^{a}$ Nitrogen and mineral composition (\%) of different organs of cacao trees are used to derive $M$ (in $10^{-3} \mathrm{~g} \mathrm{CH}_{2} \mathrm{O}\left(\mathrm{g} \mathrm{biomass}^{-1} \mathrm{~d}^{-1}\right.$; De Wit et al., 1978 ).

The mineral fraction is the sum of $\mathrm{P}, \mathrm{K}, \mathrm{Ca}$ and $\mathrm{Mg}$ concentrations (in \%).

${ }^{\mathrm{b}}$ More biochemical characteristics (all in \%) are used to calculate the growth respiration coefficient $G$ (in $\mathrm{g} \mathrm{CH}_{2} \mathrm{O}$ (g biomass) ${ }^{-1}$; Penning de Vries and Van Laar, 1982) 
1997b), as in many of the other studies light levels were rather low or seedlings were used (Murray, 1940; Lemee, 1956; Baker and Hardwick, 1973; Okali and Owusu, 1975; Hutcheon, 1977a; Guers, 1985; Raja Harun and Hardwick, 1988; Joly and Hahn, 1989; Yapp and Hadley, 1994). The value of $A_{\max }$ was adjusted for the negative effect of high temperatures (Joly and Hahn, 1989) and for the fact that young leaves are not photosynthetically active for the first days (Miyaji et al., 1997b). The value for the initial slope of the photosynthesis-light curve was $0.45\left(\mathrm{~kg} \mathrm{CO}_{2}\right.$ (ha leaf) $\left.{ }^{-1} \mathrm{~h}^{-1}\right) /\left(\mathrm{J} \mathrm{m}^{-2} \mathrm{~s}^{-1}\right)$ (Guers, 1985).

Maintenance coefficients were calculated for each organ (Table 1). Taproot and wood maintenance coefficients are not applied to the physiologically inactive heartwood, which was assumed to be formed after 10 years (cf. Hillis, 1987).

\subsubsection{Organ growth, leaf and fruit dynamics}

Assimilate requirements $\left(G ; \mathrm{kg} \mathrm{CH}_{2} \mathrm{O} \text { ( } \mathrm{kg} \text { dry weight organ }\right)^{-1}$ ) for producing biomass of the different organs is calculated based on the chemical composition of the tissue (Table 1). Assimilate requirements for fruits depend on the fat content in the seeds (nibs), following Valle et al. (1990).

Maximum leaf life span was estimated as 210 days (with optimal water availability, Miyaji et al., 1997a); the minimum as 68 days (at severe water stress due to high temperatures, Sale, 1968). Sink strength of fruit classes is related to the ripening status, with both new and almost ripe fruits having low values (Hutcheon, 1977b).

\subsubsection{Weather and soil data}

The SUCROS-Cocoa model requires daily information on minimum and maximum temperature, precipitation, radiation and vapour pressure, for a period of at least 8 years. Three types of weather data may be used as an input: (1) daily weather, (2) monthly weather data (WOFOST format; Hijmans et al., 1994) and (3) long-term average weather data with monthly values averaged over a long period. Monthly or long-term average weather data were transformed to daily values using the approach of Geng et al. (1986).

Soil data used in SUCROS-Cocoa include information on the thickness and physical characteristics of soil layers. Physical characteristics are summarised by using the 'Driessen soil types', which have standard values for water content at saturation, field capacity, wilting point and air-dry (Driessen, 1986).

\subsubsection{Validity of the model}

Simulations in SUCROS-Cocoa can be carried out for cacao trees of 3-40 y, or $18.5-70 \mathrm{~kg}$ dry weight per plant. Furthermore, the densities of model trees is bounded to $700-2500 \mathrm{ha}^{-1}$. Climatic limitations of the model are an average day temperature between 10 and $40{ }^{\circ} \mathrm{C}$, and an annual precipitation of at least 1250 $\mathrm{mm} \mathrm{y}^{-1}$ (no maximum is set as cocoa resists high rainfall when grown on favourable soils; Wood and Lass, 1985). The leaf area index (LAI) of shade trees should not exceed 3 , and soil depth should be $>1.5 \mathrm{~m}$. 


\subsection{Model simulations}

\subsubsection{General}

Simulations presented in this paper were carried out using daily, monthly and long-term average weather data of 30 locations in or close to cocoa growing areas in 10 countries (see Appendix A). These countries included seven of the top-10 cocoa-producing countries (FAO, 2003). Daily and monthly climatic data were obtained from existing databases at Wageningen University; long-term average weather data were obtained by combining information from the Müller (Müller and Hennings, 2000) and FAOCLIM (FAO, 2001) databases. Simulations were carried out using three soils that were observed in cocoa plantations (Table 2). If not indicated differently, simulations were carried out for cacao trees of initially 4 years age (ca. $20 \mathrm{~kg}$ dry weight), with a canopy between 0.75 and $3.50 \mathrm{~m}$, planted at 1000 trees $\mathrm{ha}^{-1}$, and under $10 \%$ shade of trees with a canopy of 4-10 m. Most simulations were carried out for a period of 9-11 years.

\subsubsection{Model validation}

To evaluate to what extent model predictions match the values observed in plantations, we performed a validation study. As comprehensive sets of yield and climate data for cocoa are scarce and were not available to us, we could not compare simulated to observed yields for a certain location and cropping system over a given period of time. We therefore chose to carry out a different validation (cf. Sinclair and Seligman, 2000), comparing model output after a number of model years with available plantation information on as many as possible parameters, including bean yield, standing biomass, biomass production, leaf area index, litter production and agesize relationship. When possible, simulations were carried out for the same location or country for which we had empirical data.

Table 2

Characteristics of the three soil types used in the simulations of the SUCROS-Cocoa model ${ }^{\mathrm{a}}$

\begin{tabular}{|c|c|c|c|c|c|c|}
\hline \multirow[t]{2}{*}{ Layer } & \multicolumn{2}{|c|}{ Soil 1 ('loamy') } & \multicolumn{2}{|c|}{ Soil 2 ('sandy') } & \multicolumn{2}{|c|}{ Soil 3 ('clayey') } \\
\hline & $\begin{array}{l}\text { Thickness } \\
(\mathrm{cm})\end{array}$ & $\begin{array}{l}\text { Driessen } \\
\text { type }^{b}\end{array}$ & $\begin{array}{l}\text { Thickness } \\
(\mathrm{cm})\end{array}$ & $\begin{array}{l}\text { Driessen } \\
\text { type }^{b}\end{array}$ & $\begin{array}{l}\text { Thickness } \\
(\mathrm{cm})\end{array}$ & $\begin{array}{l}\text { Driessen } \\
\text { type }^{\text {b }}\end{array}$ \\
\hline 1 & 10 & Silt loam & 9 & Coarse sand & 2 & Silt loam \\
\hline 2 & 30 & Sandy loam & 14 & $\begin{array}{l}\text { Loamy medium } \\
\text { coarse sand }\end{array}$ & 54 & Light clay \\
\hline 3 & 30 & Loamy fine sand & 12 & Sandy loam & 48 & Heavy clay \\
\hline 4 & 150 & Loamy fine sand & 119 & Sandy clay loam & 52 & Heavy clay \\
\hline
\end{tabular}

${ }^{\text {a }}$ Soil 1 is a loamy soil from cocoa plantations in Nigeria (Wessel, 1971); soil 2 is a sandy soil in plantations in Rondonia, Brazil and soil 3 is a clayey soil in a plantation in Tawau, Sabah, Malaysia (both Wood and Lass, 1985).

${ }^{\mathrm{b}}$ Volumetric water content at wilting point and field capacity (in $\mathrm{cm}^{3} \mathrm{~cm}^{-3}$ ) of the Driessen (1986) types are: silt loam: 0.108 and 0.359 ; sandy loam: 0.044 and 0.273 ; loamy fine sand: 0.027 and 0.233 ; coarse sand: 0.0001 and 0.065 ; loamy medium coarse sand: 0.031 and 0.180 ; sandy clay loam: 0.168 and 0.349 ; light clay: 0.204 and 0.378 ; heavy clay: 0.361 and 0.493 . 


\subsubsection{Sensitivity analysis}

We performed a sensitivity analysis to identify those input parameters of the model that have the largest influence on simulated yield (question (1) in Section 1). This analysis assists in identifying those parameters that are of prime importance for cocoa production, or those that require better estimates. Seventy-five input parameters (including weather data) were changed by adding or subtracting $10 \%$ and the effect on annual bean yield was calculated. Sensitivity analyses were carried out for Tawau, Sabah in Malaysia, a location with high radiation and rainfall throughout the year, and Tafo in Ghana, a location with lower radiation and a distinct dry season.

\subsubsection{Scenario studies}

Finally, scenario studies were carried out to provide an answer to questions 2-4 posed in Section 1.

Question 2 on whether rainfall and irradiance data can predict cocoa production was evaluated using simulation results for 30 locations in or close to cocoa producing regions. Simulated yield for these sites was compared to radiation and rainfall data in regression analyses. Question 3 on the yield gap due to water limitation was addressed by comparing yield for potential (i.e., non water-limiting) and water-limited production situations, for three different soil types and for 18 locations (with daily or monthly climatic data). Potential yield was simulated by constantly keeping the water content in each of the soil layers at field capacity (Van Laar et al., 1997). Question 4 on the impact of shade on cocoa yield, was addressed by modifying the LAI of shade trees between 0 and 3 , at steps of 0.5 , to simulate $0-83 \%$ shade. These simulations were carried out for three locations with contrasting rainfall and radiation patterns: Tawau in Malaysia with the highest radiation levels in our climatic dataset, and rainfall throughout the year; Tafo in Ghana with medium-high radiation and a pronounced dry period and La Lola in Costa Rica with medium-high radiation and rainfall throughout the year.

\section{Results}

\subsection{Example simulations}

To illustrate the type of output generated by SUCROS-Cocoa and to assist in the interpretation of later results, we present simulation results for two locations in more detail: Tafo in Ghana and Tawau in Malaysia (Fig. 4). The Malaysian site has the highest radiation level in our set of 30 locations and has continuous rainfall throughout the year. Here, it is apparent that fluctuations in simulated bean yield in time are correlated with those in radiation (Fig. 4(a)), as leaf area (LAI) remains constant due to the absence of periodic water shortage (Fig. 4(b)). A clearly different pattern is seen for Ghana, with marked dry periods during which LAI is reduced (Fig. 4(d)). As a result, bean yield periodically drops to very low values (Fig. 4(c)). This occurs particularly after the dry season, as at that time fruits that were produced during the dry season are ripe and ready to be harvested. The drought-induced yield reductions 


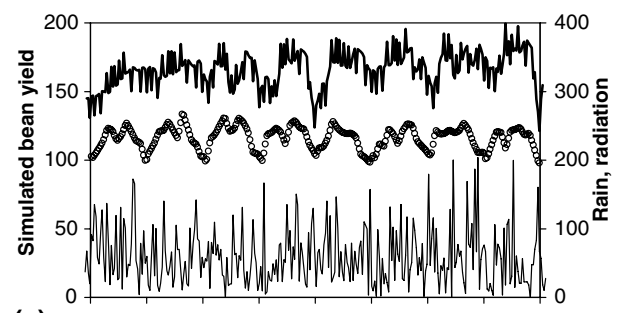

(a) 3657301095146018252190255529203285
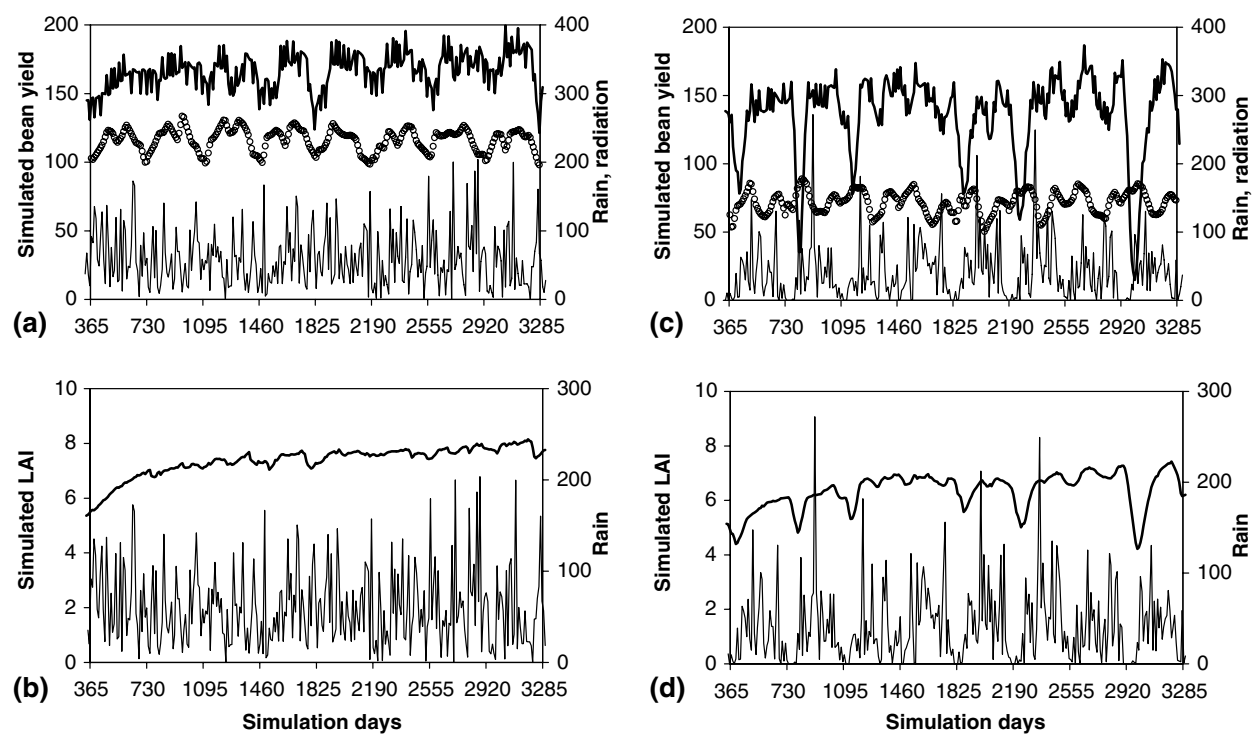

Fig. 4. Example of simulation output of the SUCROS-Cocoa model for bean yield (a, c; thick line, in kg/ ha/10 days;) and leaf area index (b,d; thick line, in ha/ha) for Tafo in Ghana (a,b) and Tawau in Malaysia $(\mathrm{c}, \mathrm{d})$ in relation to rainfall (thin lines, in $\mathrm{mm} / 10$ days) and radiation (circles, in $\mathrm{MJ} / \mathrm{m}^{2} / 10$ days). Yield, rainfall and radiation are 10-day totals, LAI is 10-day average. Results of years 2-9 of the simulations are shown. Simulations were carried out during 9-11 years for trees with an initial age of 4 years, planted at a density of 1000 trees $^{-1}$, under $10 \%$ shade and on soil type 1 (Table 2).

and the lower radiation level are the main causes for the generally lower annual yield in Ghana as compared to the Malaysian site. Thus, periodic water shortage has a strong effect on simulated yield.

\subsection{Model validation}

The SUCROS-Cocoa model was validated by comparing simulated values of various state and rate variables with those observed in cocoa plantations (Fig. 5). The most important model output parameter, annual bean yield, is comparable to observed values, when comparing values for the same country (Fig. 5(a)). For Malaysia, where most trials to increase yield have been carried out, simulated and observed values match rather closely. For Ghana and Brazil, simulated yield is considerably higher than observed, possibly because less experimental plantations have been established.

Simulated values for standing total biomass and leaf area index (LAI) of cacao trees were in the range of those observed in plantations, when comparing values for the same country or for countries in the same region (Fig. 5(b) and (e)). Two of the observed values for standing biomass were clearly much higher than the rest and also higher than the simulated values. These most probably overestimate the standing biomass as they were based on biomass measurements of the larger trees in a plantation (Malaysia; Thong and $\mathrm{Ng}, 1980$ ) or on indirect biomass estimates 

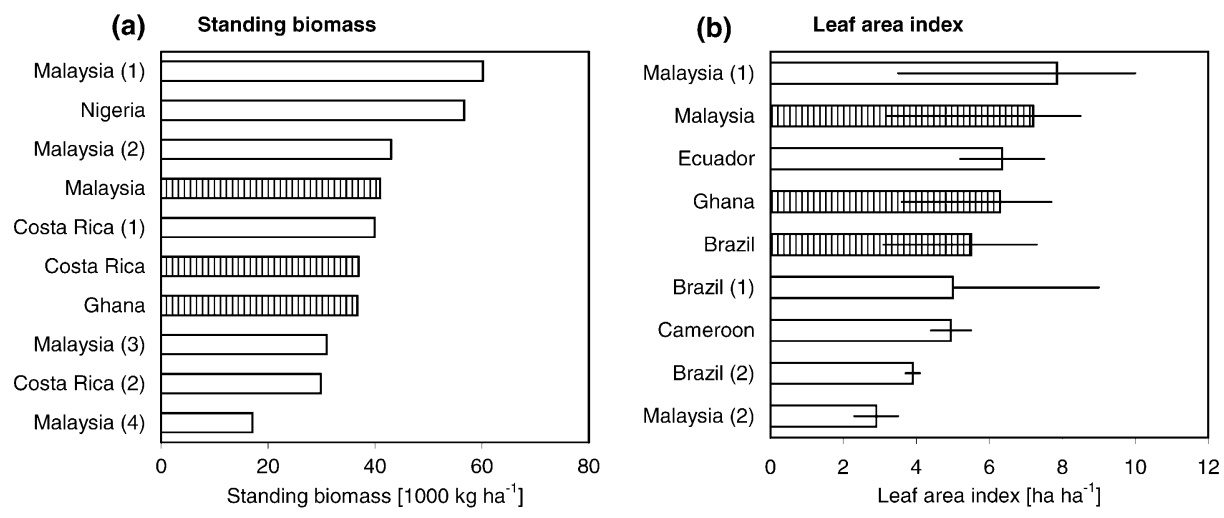

(c)

Biomass production
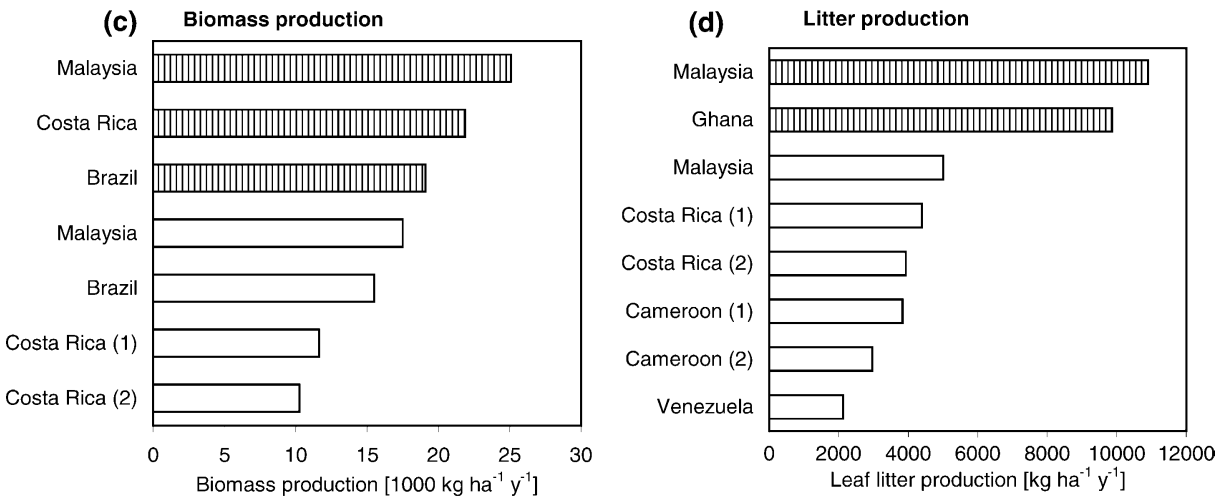

Fig. 5. Comparison of simulation results of SUCROS-Cocoa (hatched bars, $\bullet$ and $\boldsymbol{\square}$ ) with values observed in cocoa plantations (open bars in (a)-(e) and $\triangle$ in (f)) for five parameters (a-e) and tree-age relationships (f). Bars denote mean values; error bars are ranges for LAI (d). Simulations were carried out for Tawau

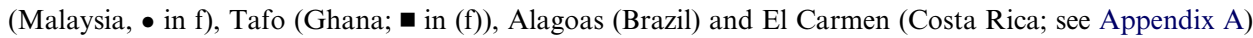
during 9-11 years using trees with an initial age of 4 years and planted at a density of 1000 trees ha $^{-1}$ on soil type 1 (Table 2). Shade level was $10 \%$, except for bean yield (a) which was simulated without shade to allow for comparison with unshaded high-yielding plantations. Simulation output is either the value of 10 year old trees $(d, e)$, the average value of trees aged 5-15 years $(a-c)$, or annual values for trees aged 3-30 years (f). Sources of observed values: Brazil 1: (Alvim, 1967); Brazil 2: (Miyaji et al., 1997a); Brazil 3: (Alvim, 1977); Brazil 4: (Alvim and Nair, 1986); Cameroon 1: (Boyer, 1970); Cameroon 2-3: (Boyer, 1973); Costa Rica 1-2: (Beer et al., 1990); Ghana: (Ahenkorah et al., 1974); Malaysia 1-2: (Thong and Ng, 1980); Malaysia 3-5: (Teoh et al., 1986); Malaysia 6: (Ling, 1986); Malaysia 7: (Yapp and Hadley, 1994); Malaysia 8: (Lim and Pang, 1990); Malaysia 9: (Lim, 1980); Malaysia 10: (Lim, 1994); Nigeria: (Opanukle, 1991); Venezuela: (Aranguren et al., 1982). The non-linear regression line in (f) explains $20 \%$ of the variation in biomass per plant, using observed values from Fig. 3. Note that the variation for the simulated LAI in (b) is due to climatic variation, whereas that of the observed values is due to variation among trees within a plantation.

of old trees in a high-density plantation (Opanukle, 1991). For leaf area index (LAI), the high LAI for Malaysia is probably also an overestimate, for the same reason.

Differences between simulated and observed values were larger for the production of biomass and litter (Fig. 5(c)-(d)). Simulated biomass production is 20-30\% higher 

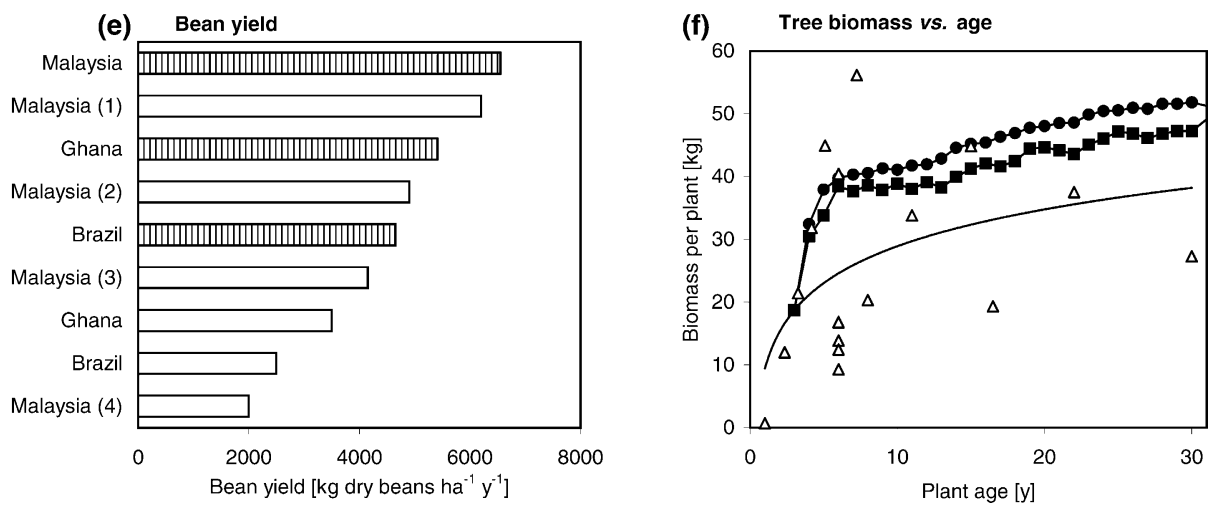

Fig. 5 (continued)

for Malaysia and Brazil, but twice as high for Costa Rica. Larger differences were found for litter production: simulated rates being two time as high as observed values for Malaysia and three times as high when simulated values for Ghana are compared with those observed in Cameroon. A possible explanation for this difference is that shaded leaves in the lower part of the crown live longer, which is not included in the model: the leaf life span value used in our model is probably better applicable to unshaded or lightly-shaded plantations than for moderately or heavily shaded cocoa. Several of the observed litter production values are for cocoa under "moderate" shade (Malaysia, Costa Rica, Venezuela), whereas the simulations were carried out for lightly shaded cooca ( $10 \%$ light interception by shade trees). Applying moderate shading $(45 \%)$ in the model results in a considerable decline in litter production.

Lastly, using information on biomass measurements of cacao trees, simulated and observed age-size relations could be compared (Fig. 5(f)). Simulated values are higher than the average observed (represented by the regression line), but generally the curvature of the regression and simulated lines are the same. The largest difference is found in the biomass increment of young cacao trees, which is much higher in the simulations than it would be expected on the basis of the observed values. Nevertheless, the large range of observed biomass values for trees of the same age indicates that the simulation results are realistic.

\subsection{Sensitivity and scenario analyses: addressing the questions}

\subsubsection{What are the most important parameters determining cocoa yield?}

Adding $10 \%$ to the value of 75 input parameters in the model had a moderate effect on simulated yield in most cases (Fig. 6). For only 4-5 of these parameters, yield was altered by more than $5 \%$ due to the change in parameter value. Changing parameter values by $10 \%$ never caused a substantial yield shift, indicating that the model is rather robust to changes in parameter values. This is a promising result, as it indicates that the model does not produce unexpected and unrealistic changes 


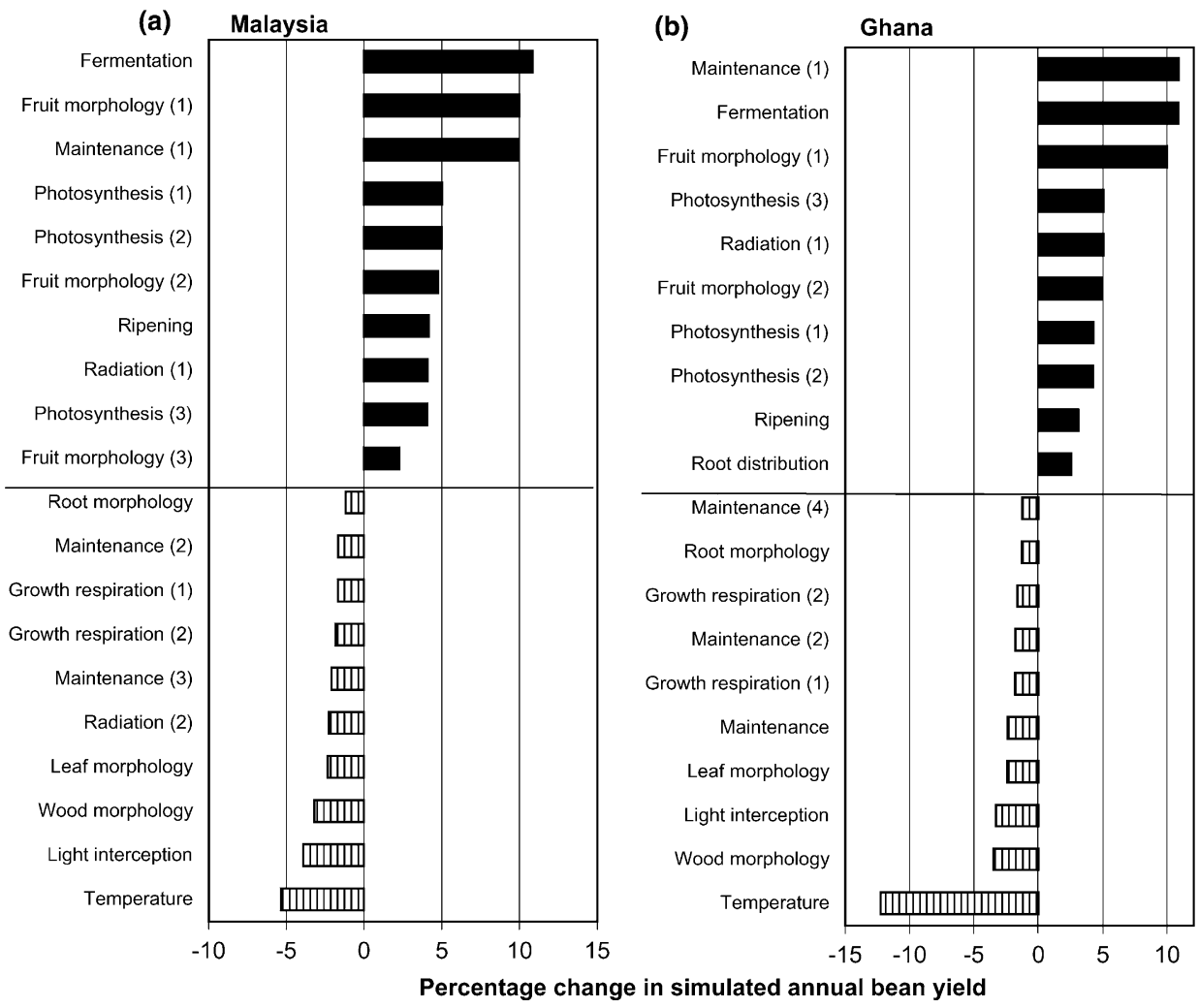

Fig. 6. Results of sensitivity analysis for annual cocoa bean yield as calculated in the SUCROS-Cocoa model for two locations: Tawau, Malaysia (a) and Tafo, Ghana (b). Shown is the percentage change in 10year average bean yield after adding $10 \%$ to the value of the parameter along the $y$-axis. Black bars denote the 10 parameters which had the strongest positive effect on bean yield; hatched bars denote the 10 parameters with the strongest negative effect. Simulations were carried out during 9-11 years for trees with an initial age of 4 years, planted at a density of 1000 trees $^{-1} a^{-1}$, under $10 \%$ shade and on soil type 1 (Table 2). Short descriptions of the parameters in alphabetic order (Zuidema et al., 2003). Fermentation $=$ coefficient in regression of biomass loss vs. fermentation time; fruit morphology (1): dry weight fraction of beans per fruit; fruit morphology (2) and (3): coefficients in regression of fruit vs. total biomass; growth respiration (1): assimilate requirements for leaf production; growth respiration (2): assimilate requirements for fruit production; leaf morphology $=$ coefficient in regression of leaf vs. total biomass; light interception $=$ extinction coefficient of leaves; maintenance (1): reference temperature for the calculation of maintenance respiration; maintenance (2): maintenance requirements for leaves; maintenance (3): maintenance requirements for wood; maintenance (4): age at which heartwood is formed; photosynthesis (1): light saturated photosynthesis rate; photosynthesis (2): factor accounting for lower photosynthesis in young leaves; photosynthesis (3): initial slope of photosynthesis-light curve; ripening = coefficient in regression of fruit ripening vs. temperature; radiation (1): fraction photosynthetically active radiation; radiation (2): total global radiation; root morphology = coefficient in regression of root vs. total biomass; root distribution $=$ coefficient in regression of fine root density vs. soil depth; temperature $=$ average temperature; wood morphology $=$ coefficient in regression of wood vs. total biomass. 
Table 3

Results of simple and multiple regression models for simulated bean yield $\left(\mathrm{kg} \mathrm{ha}^{-1} \mathrm{y}^{-1}\right)$ vs. rainfall and radiation for 30 locations, using in- and output of the SUCROS-Cocoa model ${ }^{\mathrm{a}}$

\begin{tabular}{|c|c|c|c|c|c|c|}
\hline Regression model & $\begin{array}{l}\text { Independent } \\
\text { variables }\end{array}$ & $\begin{array}{l}\text { Regression } \\
\text { coefficient }\end{array}$ & & $P$ & $\begin{array}{l}\text { Partial } \\
\text { correlation }\end{array}$ & $R^{2}$ \\
\hline \multirow[t]{2}{*}{ Single (total rain) } & Intercept & -632.4 & $(1575.9)$ & n.s. & & \multirow[t]{2}{*}{0.31} \\
\hline & Ln(TotalRain) & 758.8 & $(203.6)$ & $<0.001$ & 0.58 & \\
\hline \multirow[t]{2}{*}{ Single (dry months rain) } & Intercept & 2608.7 & (408.9) & $<0.001$ & & \multirow[t]{2}{*}{0.59} \\
\hline & Ln(Rain2DryMo) & 547.7 & $(84.0)$ & $<0.001$ & 0.78 & \\
\hline \multirow[t]{3}{*}{ Multiple (best) } & Intercept & 1142.1 & $(542.4)$ & $<0.05$ & & \multirow[t]{3}{*}{0.71} \\
\hline & Ln(Rain2DryMo) & 519.6 & $(71.4)$ & $<0.001$ & 0.81 & \\
\hline & Radiation & 0.26 & $(0.075)$ & $<0.01$ & 0.56 & \\
\hline
\end{tabular}

${ }^{\text {a }}$ Shown are results of single regressions with total annual rainfall $\left(\mathrm{mm} \mathrm{y}^{-1}\right)$ or rainfall during two driest months as independent variables; and of the multiple regression with the best fit with radiation $\left(\mathrm{MJ} \mathrm{m}^{-2} \mathrm{y}^{-1}\right)$ and rainfall data as independent variables. Regression coefficients (and SE), $P$-values, partial correlations and coefficients of determination $\left(R^{2}\right)$ are shown.

in output as a result of small changes in input parameters. The results of the sensitivity analysis for Malaysia and Ghana were very similar, in spite of the differences in climate (see Fig. 6). When 10\% of the parameter values were subtracted (instead of added), results were also very similar (not shown).

A detailed look at the parameters with the largest positive effect on yield shows that these are related to morphology, ripening and processing of fruits (4-5 out of $10)$, to photosynthesis and light interception (4), and to maintenance respiration (1). Especially the weight fraction of beans per fruit, the weight fraction of beans after fermentation and the reference temperature used in the calculation of the maintenance respiration have an almost one-to-one relation with simulated yield. The first two parameters are used in simple calculations to derive the yield of fermented beans from the fruit yield output of the simulated growth. The third parameter is the temperature value related to maintenance costs: above this temperature, maintenance respiration increases with increasing temperature, thus indirectly lowering bean yield (De Wit et al., 1978). High values for this temperature have a positive effect on bean yield, as they reduce the temperature-related maintenance costs. Parameters with the largest negative impact on yield are mainly related to maintenance and growth respiration (4-5). A negative one-to-one relation with yield was only found for temperature in the case of Ghana, which is related to the increase in maintenance costs, thus causing a lower fruit production.

\subsubsection{To what extent can rainfall and irradiance data predict cocoa production?}

Simulations for 30 different locations in 10 countries revealed large differences in cocoa production: annual bean yield varied from $4108 \mathrm{~kg} \mathrm{ha}^{-1} \mathrm{y}^{-1}$ in the Philippines to $6126 \mathrm{~kg} \mathrm{ha}^{-1} \mathrm{y}^{-1}$ in Malaysia (Appendix A). These locations also differed largely in total rainfall, rainfall distribution and the amount of radiation. Regression analyses revealed that simulated cocoa yield was well-correlated with total annual rainfall, but also with rainfall during the driest months of the year (Table 3). The best 


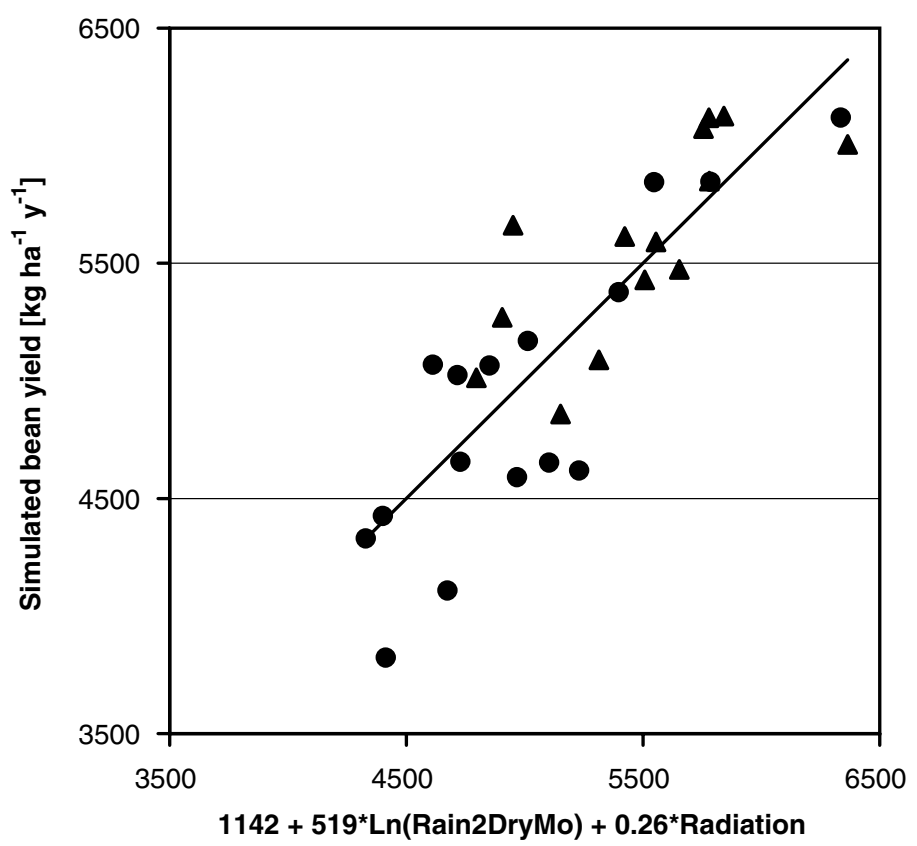

Fig. 7. Relation between annual cocoa bean yield as simulated in SUCROS-Cocoa and the combination of dry-season rainfall and radiation for 30 locations in 10 countries (circles for daily or monthly climate data; triangles for long-term climate data). The calculation of values along the $x$-axis is based on a multiple regression analysis (Table 3$)$ and is calculated using annual radiation $\left(\mathrm{MJ} \mathrm{m}^{-2} \mathrm{y}^{-1}\right)$ and rainfall during the two driest months $(\mathrm{mm})$. The regression line explains $71 \%$ of the variation in simulated bean yield. Simulations were carried out during 9-11 years for trees with an initial age of 4 years, planted at a density of 1000 trees $\mathrm{ha}^{-1}$, under $10 \%$ shade and on soil type 1 (Table 2).

regression model explained over $70 \%$ of the variation in simulated bean yield by a combination of total annual radiation and rainfall during the two driest months (Table 3, Fig. 7). Partial correlations showed that bean yield was more closely related to dry-period rainfall than to radiation.

From the regression analyses it became clear that the amount of rain during the driest months was more important in determining yield than total annual rainfall. A single linear regression of yield against total annual rainfall explained $34 \%$ of the variation, whereas one for rainfall during the two driest months explained $58 \%$. This result can be understood when considering the impact of periodic water shortage on bean yield for Ghana as shown in Fig. 4.

\subsubsection{How large is the cocoa 'yield gap' due to water limitation?}

The yield gap (difference between simulated yield for potential and water-limited situations) depended both on rainfall and on soil type, as is shown in Fig. 8. Strong correlations were found between (ln-transformed) rainfall during the dry period and yield gap. For any given amount of rain, the yield gaps for sandy and clayey soils were very similar. Yield gaps for these soils were substantially higher than for the more 


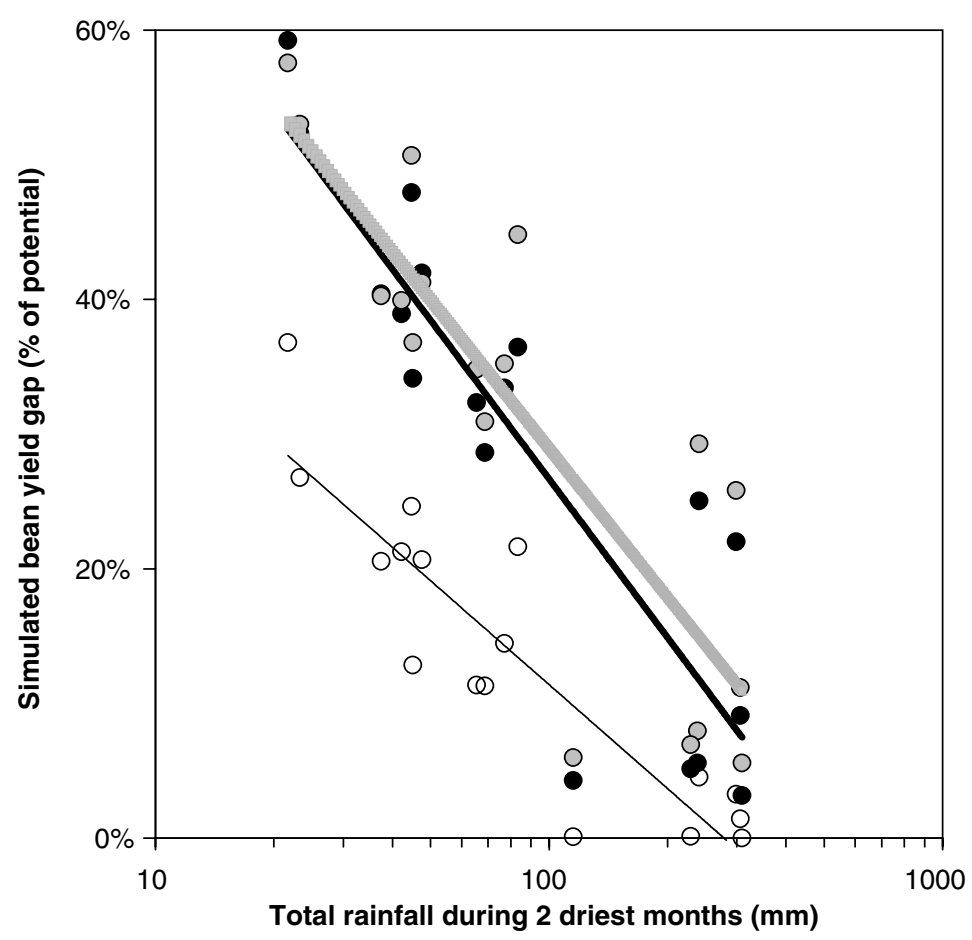

Fig. 8. The relation between cocoa yield gap due to water shortage (as simulated in the SUCROS-Cocoa model) and rainfall during the two driest months, for three different soils (open for 'loamy', black for 'sandy' and grey for 'clayey' soil; Table 2) and 18 locations (with daily or monthly climatic data). The yield gap is expressed as a percentage of the potential yield (i.e., (potential - water-limited)/ potential). $R^{2}$ values of regressions were 0.82 ('loamy'), 0.78 ('sandy') and 0.73 ('clayey'). Simulations were carried out during 9-11 years for trees with an initial age of 4 years, planted at a density of 1000 trees ha $^{-1}$ and under $10 \%$ shade.

favourable loamy soil. In fact, in the loamy soil, no yield gap was found for locations with a relatively high amount of rainfall during the months with lowest precipitation. The model simulations suggest that cocoa plantations on unfavourable soils that receive less than $50 \mathrm{~mm}$ of rain during the two driest months, would produce less than $60 \%$ of their potential under optimal water supply. The simulations also suggest that the yield gap is logarithmically (and negatively) related to dry-season rainfall.

\subsubsection{What are the consequences of shading on cocoa yield?}

The heavy shade regimes ( $>70 \%$ shade) could not be simulated for all three locations (Fig. 9). Cacao trees under heavy shade in Costa Rica (La Lola) and Ghana (Tafo) completely depleted their reserves in the model, whereas those in Malaysia survived under $83 \%$ shade. This difference is probably explained by the considerably higher radiation levels in Malaysia (Tawau) compared to the other locations (see Appendix A). Increased shading caused a similar reduction in bean yield for the three locations (Fig. $9(a)$ ). Yield reduction was only $10 \%$ when shading was less than $25 \%$, but it was more 
(a)

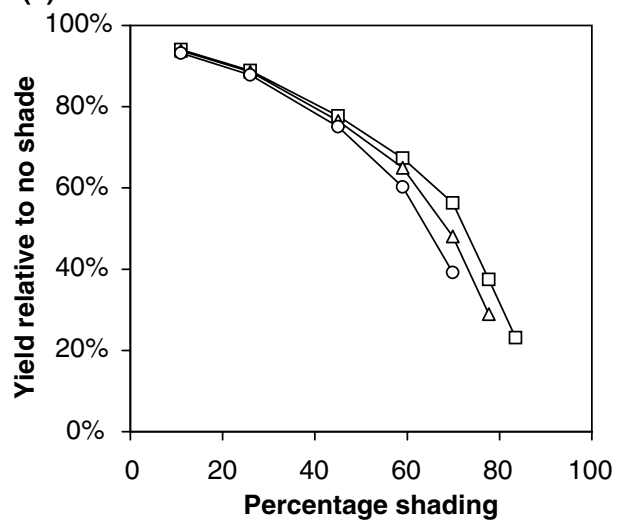

(b)

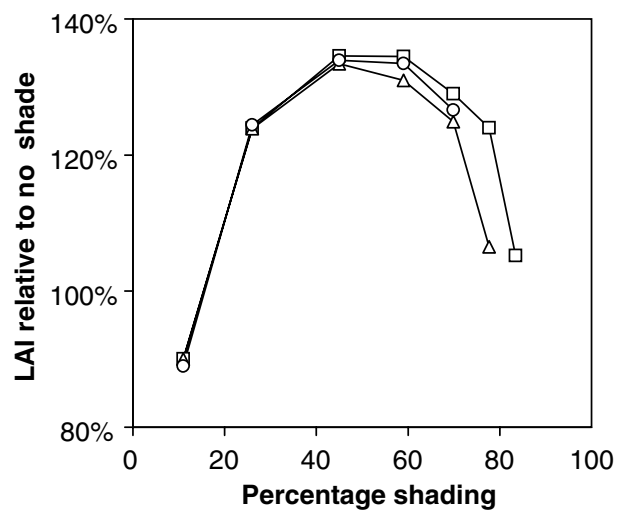

Fig. 9. The effect of shading on simulated annual cocoa bean yield (a) and leaf area index (LAI, b) for three locations ( $\square$ : Tawau, Malaysia; $\triangle$ : Tafo, Ghana; $\circ$ : La Lola, Costa Rica; see Appendix A), using the SUCROS-Cocoa model. Yield and LAI values are averaged over 10 years. Percentage shading is calculated as $100 \%$ minus the percentage light transmitted through the shade tree layer. Shade levels were modified by changing LAI values for shade trees. Simulations were carried out during 9-11 years for trees

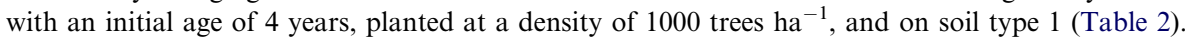

than one-third for shade levels of $>60 \%$. The moderate reduction in simulated yield for lightly shaded cocoa is explained by an increase in leaf area at intermediate shade levels (Fig. 9(b)). A positive relation between shade level and SLA (specific leaf area; cf. Guers, 1971) causes the LAI (leaf area per unit soil area) to increase. At high shade levels, LAI decreases again as model trees remain small due to the limited radiation.

\section{Discussion}

\subsection{Model evaluation and application}

The SUCROS-Cocoa model was able to simulate cacao tree growth and production over long periods, up to 40 years, in many different locations and cropping systems. It produced realistic output, particularly for the most relevant parameter, bean yield, but also for standing biomass, leaf area index and age-size relations (Fig. 5). Deviations of model output and empirical data on biomass production and litter production possibly point to limitations of the model (see Section 4.3). However, some of the empirical data are of limited value (e.g., due to selective sampling or indirect estimation), which makes validation somewhat difficult. Our model also proved to simulate realistic values over long simulation periods, as problems of accumulated errors were partly circumvented by letting trees grow according to allometric rules (Fig. 3).

As in all models, the assumptions implicit in the SUCROS-Cocoa model determine its applicability and provide the context for the interpretation of model output. Two main assumptions of SUCROS-Cocoa are that there is no shortage of nutrients 
and no incidence of pests and diseases. In practice this implies that the model output is best compared to empirical data obtained in plantations which are fertilised and relatively free of pests and diseases. It also implies that simulated yield levels are much higher than national averages (FAO, 2003). A third main assumption is that the canopies of shade trees and cacao trees are closed and homogeneous. This requires model trees to be sufficiently large and to occur at a sufficient density. This is achieved by putting a minimum to tree density and size (or age). It also implies that the number of leaf layers (LAI) of shade trees and cacao trees is the same at any location within the modelled plantation. We are aware that this strongly contrasts to the actual practice of shading in many plantations, which is typically highly heterogeneous in horizontal space (cf. Hadfield, 1981; Mialet-Serra et al., 2001). Nevertheless, the shade scenario studies are useful to answer 'what-if' questions on shade treatments. Further, simulation results for different shade levels can be combined to estimate yield of a plantation with a patchy shading pattern, if the proportion of the area under different shade intensities is known (e.g., Mialet-Serra et al., 2001). A fourth assumption is that model trees do not show senescence: growth and yield is not reduced for old or large trees. This assumption is taken into account by setting a maximum to the size (and thus implicitly age) of model trees. To the extent that senescence importantly limits growth and yield, the model overestimates productivity for old plantations. The fifth and last important assumption is that model trees are not pruned, in contrast to real plantation trees. No biomass is removed from the model trees, although the allometric relations (Fig. 3) used for the distribution of assimilates is partly based on trees that were most probably pruned periodically. Thus, indirectly, the longer-term effects of pruning on biomass distribution among organs may be included, but the short-term consequences of pruning on light interception, biomass distribution and yield are not. The lower and upper height of the canopy of model trees is predetermined in the model, thus mimicking one of the consequences of pruning.

In summary, the SUCROS-Cocoa model can be applied to obtain reasonable estimates of cocoa growth and yield throughout (potential) cocoa production areas. Nevertheless, the results should be interpreted with some care, given various assumptions and data limitation.

\subsection{Answering the questions}

\subsubsection{What are the most important parameters determining cocoa yield?}

There was little difference in output of the sensitivity analysis between Malaysia (Tawau) and Ghana (Tafo), in spite of the $40 \%$ lower radiation and $25 \%$ lower rainfall in Ghana (Fig. 6). This suggests that using the current set of parameters, sensitivity analysis for other locations and soil types will probably produce similar lists of most important parameters.

The most important parameters were related to fruit morphology and bean fermentation, to light interception and photosynthesis, and to maintenance respiration. Understandably, these three categories are crucial to the production of beans, and confirm the findings of earlier cocoa production studies (e.g., Yapp and Hadley, 
1994). The first category includes parameters that have simple relations with simulated bean yield, as they are used to convert the simulated fruit production rates into fermented bean yield. Changes in these parameters therefore directly change bean yield, but do not alter the simulation of plant growth. In contrast, the other two categories include processes that are central to the growth simulations and which have multiple and complex consequences for model output. The importance of the interception and photosynthesis suggests that bean production is light-limited, probably due to external and internal shading in the cacao stand and the extinction of light in the canopy (cf. Yapp and Hadley, 1994). The high sensitivity of the model to the light-saturated photosynthesis $\left(A_{\max }\right)$ and the photosynthetic efficiency at low light implies that parameter uncertainty may have a large impact on model output. $A_{\max }$ has been estimated in various studies (see references in Section 2), which yielded highly different values, probably due to sub-optimal conditions in several studies. For the initial photosynthetic efficiency, only one value was available (Guers, 1985), but this parameter does not show much variation (Ehleringer and Pearcy, 1983). In both cases, it is evident that more high-quality data are required to improve the reliability of model output. As for the last category of parameters with high sensitivity (maintenance respiration), this includes the maximum temperature for which there is no temperature-dependent maintenance respiration $\left(25^{\circ} \mathrm{C}\right)$. The high sensitivity of simulated bean yield to changes in these parameters shows that maintenance respiration is an important sink of carbohydrates.

\subsubsection{To what extent can rainfall and irradiance data predict cocoa production?}

Annual radiation and rainfall during the dry season explained $70 \%$ of the variation in simulated annual bean yield obtained for 30 locations throughout the Tropics (Table 3 ). This suggests that using readily available climate data, cocoa production may be predicted to a certain extent. However, these relations are based on model input and output, and cannot be confirmed for actual cocoa yield due to lacking information. Therefore, these results should be interpreted cautiously, as they depend on the assumptions of the model. In particular, the way in which consequences of water shortage are modelled may have important consequences for the output (see Section 4.3). Nevertheless, there is empirical evidence supporting our simulation results. Positive correlations between yield and rainfall during months preceding fruiting were found for Papua New Guinea (Bridgland, 1953). And in Ghana, rather strong positive correlations were found between dry-season rainfall and the subsequent cocoa yields (Ali, 1969), which confirms the results of our regression analyses.

\subsubsection{How large is the cocoa 'yield gap' due to water limitation?}

Simulations showed that the yield gap due to water limitation may be large: up to $50 \%$ in some cases (Fig. 8). The yield gap is strongly (and negatively) related to the dry-season precipitation and furthermore depends on soil type. The low water retention capacity of clayey and sandy soils resulted in much higher yield gaps than in the loamy soil. The values of the simulated yield gaps depend on the way in which the response of cacao trees to water shortage (leaf shedding, changed bio- 
mass partitioning) has been modelled. As physiological insights on this response are lacking, the results of the yield gap analysis should be interpreted with some care (see also Section 4.3).

\subsubsection{What are the consequences of shading on cocoa yield?}

The simulations show that heavy shading strongly reduced bean yield (Fig. 9). This is in agreement with results of the shade and manurial experiment in Ghana (Ahenkorah et al., 1974), in which similarly strong reductions in yield were observed due to shading. The higher production of unshaded cocoa comes at a cost of a shorter (productive) life time of cacao trees, very high fertiliser requirements and higher susceptibility to pests and diseases (cf. Ahenkorah et al., 1974). Unshaded plantations therefore require a considerably higher level of investment. The faster senescence of unshaded cacao trees, the increased fertiliser requirements and the higher risk of pests and diseases are not included in our model, but any comparison of simulated bean yield in shaded and unshaded situations should take these important differences into account.

The application of light to moderate shading in the model resulted in small reductions of bean yield (Fig. 9), as in these situations the leaf area is increased due the production of thinner leaves (higher SLA). Although the adaptation of SLA to shading is based on empirical data (Guers, 1971), it results in relatively high values for LAI. Empirical information and model adjustments are needed to improve the way in which shade adaptation is modelled (see Section 4.3).

\subsection{Model development}

The SUCROS-Cocoa model exploits a large amount of published knowledge on the physiology and agronomy of the cacao tree. This information is used to simulate cacao physiology, growth and reproduction. Further improvement of the model can be achieved in two ways. First, some improvement of the model can be realised by additional information for a better parameterisation of the model. The sensitivity analysis presented here provides guidance to those parameters that have the strongest effect on bean yield. Especially those parameters that are both important in determining model output, and are poorly estimated (e.g., light-saturated photosynthesis rate, initial photosynthesis efficiency) should be given attention. The model could also be improved when it would be parameterised and validated for a well-studied cacao variety.

Second, substantial model improvement can be achieved by incorporating new insights in cocoa physiology and growth, i.e. by adapting certain simulation processes in the model. The model validation and the scenario studies presented here provide some guidance for the most relevant issues:

(1) Periodic water shortage. Regression analyses show that simulated bean yield is closely correlated to dry-period rainfall (Table 3). This implies that the way in which model trees respond to water shortage determines to a large extent the bean yield. Consequences of water limitation on cacao trees are modelled based on generally applicable physiological knowledge (on changed partitioning and leaf dynamics) 
rather than specific knowledge on cocoa. For instance, the relation between water availability and photosynthesis not known for cacao trees, but assumed to be linear (and positive). Similarly, the relation between leaf life span and leaf production on the one hand and water availability on the other was also assumed to be linear (and negative) as no information on alternative types of relations is currently available. Given the importance of these relations for simulated bean yield, it is crucial that more insight is gained in the physiological and morphological responses of cacao trees to water stress.

(2) Shading. The current version of SUCROS-Cocoa seems to produce reasonable estimates of yield reduction in the presence of moderate to heavy shading. However, the model estimates rather unrealistic values for leaf area index (LAI) at intermediate shade levels. There is also a need to validate the simulation results, but information on yield gaps due to shading is scarce (Ahenkorah et al., 1974). Furthermore, the physiology of trees under heavy shade is likely to be different in reality as shaded trees may be more efficient in photosynthesis and leaf dynamics (e.g., increased leaf life span; Miyaji et al., 1997a). Such adaptations have not been incorporated in the model.

(3) Leaf dynamics. Several factors influence the rate of production and abscission of leaves. Two of these factors - light availability and water availability - vary largely among locations and cropping systems. As the goal of SUCROS-Cocoa is to compare simulated production in different regions and cropping systems, it may be important to model leaf dynamics in relation to these parameters. This would require more insight in these relations and a substantial adaptations of the leaf dynamics part of the model.

\section{Conclusion}

Given the growing demand for cocoa worldwide, the quest for obtaining sustainable production systems and the debate on applying shade in cocoa plantations (e.g., Wessel and Gerritsma, 1994), a cocoa production model may be useful to provide part of the information necessary to address these issues and to guide the cocoa research agenda. We showed that the SUCROS-Cocoa model can provide answers and guidance on these issues.

\section{Acknowledgements}

Many persons contributed to the development of the SUCROS-Cocoa (previously "CASE2") model. We especially acknowledge the continuous and stimulating support of Jan Goudriaan, Rudy Rabbinge and Marius Wessel in this process. Weather data were kindly made available by various persons at Wageningen University and Research Centre. The model (on cd-rom) and reports (Zuidema and Leffelaar, 2002a,b; Zuidema et al., 2003) are freely available upon request, and the latter can also be downloaded from Wageningen University Library (library.wur.nl). 


\section{Appendix A.}

Climatic information and bean yield as simulated with SUCROS-Cocoa for 30 locations in 10 countries in or close to cocoa-growing areas

\begin{tabular}{|c|c|c|c|c|c|c|c|c|}
\hline Country & $\begin{array}{l}\text { Location } \\
\text { name }\end{array}$ & Latitude & Longitude & Period & Type & Radiation & Rainfall & Yield \\
\hline Brazil & Belem & -1.5 & -48.5 & - & 1 & 6939 & 2784 & 6119 \\
\hline Brazil & Salvador & -12.9 & -38.3 & - & 1 & 6977 & 1859 & 5474 \\
\hline Brazil & Vitoria & -20.3 & -40.3 & - & 1 & 6407 & 1483 & 5089 \\
\hline Cameroon & Batouri & 4.5 & 14.4 & - & 1 & 6063 & 1722 & 5269 \\
\hline Cameroon & Douala & 4 & 9.7 & - & 1 & 5409 & 4475 & 5662 \\
\hline Colombia & Andagoya & 5.1 & -76.7 & - & 1 & 6090 & 7109 & 6005 \\
\hline Colombia & Villavicencio & 4.2 & -73.6 & - & 1 & 6088 & 4072 & 5614 \\
\hline Costa Rica & El Carmen & 10.2 & -83.5 & 18 & d & 5366 & 3536 & 5377 \\
\hline Costa Rica & La Lola & 10.1 & -83.4 & 18 & $\mathrm{~d}$ & 4329 & 3279 & 4652 \\
\hline Costa Rica & La Mola & 10.4 & -83.8 & 12 & $\mathrm{~d}$ & 4731 & 3714 & 5065 \\
\hline Costa Rica & Puerto Limon & 10 & -83.1 & 21 & d & 4221 & 3215 & 4618 \\
\hline Ghana & Hon & 6.6 & 0.5 & - & 1 & 6424 & 1480 & 4860 \\
\hline Ghana & Kumasi & 6.7 & -1.6 & - & 1 & 5905 & 1449 & 5013 \\
\hline Ghana & Tafo & 6.3 & -0.4 & 35 & $\mathrm{~m}$ & 5236 & 1512 & 5023 \\
\hline Indonesia & Bah Lias & 3.2 & 99.3 & 15 & $\mathrm{~m}$ & 5921 & 1538 & 5845 \\
\hline Ivory Coast & Abidjan & 5.3 & -3.9 & 10 & $\mathrm{~m}$ & 6009 & 1473 & 4656 \\
\hline Ivory Coast & Daloa & 6.9 & -6.4 & 10 & $\mathrm{~m}$ & 5902 & 1043 & 4329 \\
\hline Ivory Coast & Dimbokro & 6.7 & -4.7 & 10 & $\mathrm{~m}$ & 6365 & 1058 & 3823 \\
\hline Ivory Coast & Gagnoa & 6.1 & -5.9 & 12 & $\mathrm{~m}$ & 5674 & 1278 & 5068 \\
\hline Ivory Coast & Man & 7.4 & -7.5 & 10 & $\mathrm{~m}$ & 6140 & 1748 & 5169 \\
\hline Ivory Coast & San Pedro & 4.8 & -6.6 & 10 & $\mathrm{~m}$ & 5233 & 1207 & 4425 \\
\hline Malaysia & $\begin{array}{l}\text { Kuala } \\
\text { Trengganu }\end{array}$ & 5.3 & 103.1 & - & 1 & 6839 & 3003 & 6072 \\
\hline Malaysia & Penang & 5.3 & 100.3 & - & 1 & 6850 & 2974 & 5429 \\
\hline Malaysia & Sandakan & 5.9 & 118.1 & - & 1 & 6784 & 3261 & 6126 \\
\hline Malaysia & Tawau (Sabah) & 5.0 & 117.9 & 43 & $\mathrm{~m}$ & 8489 & 2169 & 6118 \\
\hline Malaysia & Telok Chengai & 6.1 & 100.3 & 11 & $\mathrm{~m}$ & 7041 & 2219 & 4589 \\
\hline Papua New Guinea & Dami & -5.5 & 150 & 22 & $\mathrm{~d}$ & 6349 & 3811 & 5845 \\
\hline Papua New Guinea & Madang & -5.2 & 145.8 & - & 1 & 6563 & 3754 & 5850 \\
\hline Papua New Guinea & Rabaul & -4.2 & 152.2 & - & 1 & 6341 & 2107 & 5592 \\
\hline Philippines & $\begin{array}{l}\text { IRRI wet } \\
\text { station }\end{array}$ & 14.2 & 121.3 & 17 & d & 6042 & 2054 & 4108 \\
\hline
\end{tabular}

Geographical position $\left({ }^{\circ}\right)$, period of weather data $(\mathrm{y})$ and type of weather data $(\mathrm{d}=$ daily, $\mathrm{m}=$ monthly, $1=$ long-term average), annual radiation $\left(\mathrm{MJ} \mathrm{m}^{-2} \mathrm{y}^{-1}\right)$, rainfall $\left(\mathrm{mm} \mathrm{y}^{-1}\right)$ and simulated yield are shown $\left(\mathrm{kg} \mathrm{ha}^{-1} \mathrm{y}^{-1}\right)$. Simulations were carried out during 9-11 years for trees with an initial age of 4 years, planted at a density of 1000 trees ha $^{-1}$, under $10 \%$ shade and on soil type 1 (Table 2). Elevation of weather stations ranged from 0 to $650 \mathrm{~m}$ a.s.l. Period is not applicable for long-term weather data.

\section{References}

Ahenkorah, Y., Akrofi, G.S., Adri, A.K., 1974. The end of the first cocoa shade and manurial experiment at the Cocoa Research Institute of Ghana. J. Hortic. Sci. 49, 43-51.

Ali, F.M., 1969. Effects of rainfall on yield of cocoa in Ghana. Exp. Agric. 5, 209-213.

Alpízar, L., Fassbender, H.W., Heuveldop, J., Fölster, H., Enríquez, G., 1986. Modelling agroforestry systems of cacao (Theobroma cacao) with laurel (Cordia alliodora) or poro (Erythrina poeppigiana) in Costa Rica. I. Inventory of organic matter and nutrients. Agrofor. Syst. 4, 175-189.

Alvim, P.deT, 1960. Stomatal opening as a practical indicator of moisture deficiency in cacao. Phyton 15 , 79-89. 
Alvim, P.de T., 1967. Eco-physiology of the cacao tree. Conf. Int. Rech. Agron. Cacaoyères, 23-35.

Alvim, P. de T., 1977. Ecological and physiological determinants of cacao yield. In: Proceedings of the 5th International Cocoa Research Conference, pp. 25-38.

Alvim, R., Nair, P.K.R., 1986. Combination of cacao with other plantation crops: an agroforestry system in Southeast Bahia, Brazil. Agrofor. Syst. 4, 3-15.

Alvim, R., Alvim, P.de T., 1977. Hydroperiodicity in cocoa tree. In: Proceedings of the 5th International Cocoa Research Conference, pp. 204-209.

Anten, N.P.R., Gerritsma, W., Wessel, M., 1993. Modelling as a tool for cocoa research, preliminary results. In: Proceedings of the 11th International Cocoa Research Conference, Yamoussoukro, Ivory Coast.

Aranguren, J., Escalante, G., Herrera, R., 1982. Nitrogen cycle of perennial crops under shade trees II Cacao. Plant Soil 67, 259-269.

Baker, N.R., Hardwick, K., 1973. Biochemical and physiological aspects of leaf development in cocoa (Theobroma cacao L.). I. Development of chlorophyll and photosynthetic activity. New Phytol. 72, 1315-1324.

Balasimha, D., 1991. A whole-plant structure: function model for cocoa. J. Plant. Crops 18, 65-71.

Beer, J., Bonneman, A., Chavez, W., Fassbender, H.W., Imbach, A.C., Martel, I., 1990. Modelling agroforestry systems of cacao (Theobroma cacao) with laurel (Cordia alliodora) or poro (Erythrina poeppigiana) in Costa Rica. V. Productivity indices, organic material models and sustainability over ten years. Agrofor. Syst. 12, 229-249.

Bouman, B.A.M., Kropff, M.J., Tuong, T.P., Wopereis, M.C.S., Ten Berge, H.F.M., Van Laar, H.H., 2001. ORYZA2000: modeling lowland rice. IRRI/Wageningen University.

Boyer, J., 1970. Influence des régimes hydriqye, radiatif et thermique du climat sur l'activité végétative et la floraison de cacaoyers cultivés au Cameroun. Café Cacao Thé, 14,189-201.

Boyer, J., 1971. Étude des principales composantes du microclimat d'une cacaoyère au Cameroun, importance écologique des variations spatiales et saisonniè. Café Cacao Thé 15, 275-299.

Boyer, J., 1973. Etude particuliere des facteurs hydriques de la croissance des cacaoyers. Café Cacao The 15, 189-203.

Bridgland, L.A., 1953. Study if the relationship between cacao yield and rainfall Papua New Guinea. Agric. Gazz. 8, 7-14.

Cannell, M.G.R., 1985. Dry matter partitioning in tree crops. In: Cannell, M.G.R., Jackson, J.E. (Eds.), Attributes of Trees as Crop Plants. ITE/Wilson, UK, pp. 160-193.

De Wit, C.T., et al., 1978. Simulation of assimilation and transpiration of crops. Simulation monograph. Pudoc, Wageningen.

Driessen, P.M., 1986. The water balance of the soil. In: Van Keulen, H., Wolf, J. (Eds.), Modelling of Agricultural Production: Weather, Soils and Crops. Pudoc, Wageningen, pp. 76-116.

Ehleringer, J., Pearcy, R.W., 1983. Variation in quantum yields for CO2 uptake in C3 and C4 plants. Plant Physiol. 73, 555-559.

FAO, 2001. FAOCLIM. Cd-rom. Environment and natural resources service (SDRN) Working Papers 5. FAO, Rome.

FAO, 2003. FAOSTAT Agriculture data. <http://apps.fao.org> (accessed 07.11.03.).

Fassbender, H.W., Beer, J., Heuveldop, J., Imbach, A., Enriquez, G., Bonneman, A., 1991. Ten year balances of organic matter and nutrients in agroforestry systems at CATIE. Costa Rica Forest Ecol. Manage. 45, 173-183.

Geng, S., Penning de Vries, F.W.T., Supit, I., 1986. A simple method for generating daily rainfall data. Agric. For. Meteorol. 36, 363-376.

Gerritsma, W., Wessel, M., 1999. CASE2, a model for cocoa growth and production. In: Proceedings of the 12th International Cocoa Research Conference, Salvador, Bahia, Brazil.

Goudriaan, J., Van Laar, H.H., 1994. Modelling Potential Crop Growth Processes Current Issues in Production Ecology 2. Kluwer, Dordrecht.

Goudriaan, J., Van Roermund, H.J.W., 1999. Modelling of ageing, development, delays and dispersion. In: Leffelaar, P.A. (Ed.), On Systems Analysis and Simulation of Ecological Processes. Kluwer, Dordrecht, pp. 89-126. 
Guers, J., 1971. Influence des conditions d'éclairement et de température sur la teneur en chlorophylles et l'activité phot osynthétique des feuilles de cacaoyer. Café Cacao Thé 18, 157-166.

Guers, J., 1985. Potentialités photosynthètiques du cacoyer (Theobroma cacao L.) en fonction de l'eclairement, de la temperature et du $\mathrm{CO}_{2}$ ambiant. Café Cacao Thé 29, 245-254.

Hadfield, W., 1981. Canopy architecture of some Ecuadorian cocoa populations with special reference to light penetration. In: Proceedings of the 7th International Cocoa Research Conference, pp. 109120.

Hadley, P., End, M., Taylor, S.T., Pettipher, G.L., 1994. Environmental regulation of vegetative and reproductive growth in cocoa grown in controlled glasshouse conditions. In: Proceedings of the International Cocoa Conference: Challenges in the 90s, pp. 319-331.

Hijmans, R.J., Guiking-Lens, I.M., Van Diepen, C.A., 1994. WOFOST 6.0: user's guide for the WOFOST 6.0 crop growth simulation model. Technical Documents, Winand Staring Centre, Wageningen.

Hillis, W.E., 1987. Heartwood and Tree Exudates. Springer, Berlin.

Humphries, E.C., 1944. Some problems of cacao fermentation. Trop. Agric. 21, 166-169.

Hutcheon, W.V., 1976. A framework for physiology of cocoa. Cocoa Growers Bull. 25, 5-10.

Hutcheon, W.V., 1977a. Growth and photosynthesis of cocoa relation to environmental and internal factors. In: Proceedings of the 5th International Cocoa Research Conference, pp. 222-223.

Hutcheon, W.V., 1977b. Water relations and other factors regulating the seasonal periodicity and productivity of cocoa in Ghana. In: Proceedings of the 5th International Cocoa Research Conference, pp. 233-244.

Joly, R.J., Hahn, D.T., 1989. Net $\mathrm{CO}_{2}$ assimilation of cacao seedlings during periods of water deficit. Photosynth. Res., 21,151-159.

Kelliher, F.M., Leuning, R., Raupach, M.R., Schulze, E.D., 1995. Maximum conductances for evaporation from global vegetation types. Agric. For. Meteorol. 73, 1-16.

Kropff, M.J., Van Laar, H.H., 1993. Modelling crop-weed interactions. CAB International, Wallingford.

Kummerow, J., Kummerow, A., Alvim, P.de T., 1981. Root biomass in a mature cacao (Theobroma cacao L.) plantation. Rev. Theobroma 11, 77-85.

Kummerow, J., Kummerow, M., Da Silva, W.S., 1982. Fine root growth dynamics in cacao (Theobroma cacaoL.). Plant Soil 65, 193-201.

Leffelaar, P.A., 1999. On Systems Analysis and Simulation of Ecological Processes. With Examples in CSMP and Fortran. Kluwer, Dordrecht.

Lemée, G., 1956. Recherches eco-physiologiques sur le cacaoyer. Rev. Gén. Bot. 63, 41-96.

Lim, D.H.K., 1980. New developments in shade for hybrid cocoa in Sabah. In: Proceedings of the International conference on Cocoa and Cocunuts. Incorporated Society of Planters, Kuala Lumpur.

Lim, D.H.K., 1994. Development and management of plantation cocoa on scientific guidelines. In: Chee, K.H. (Ed.), Management for Enhanced Profitability in Plantations. Inc. Society of Planters, Kuala Lumpur, pp. 177-190.

Lim, D.H.K., Pang, T.Y., 1990. Advances in cocoa planting densities/patterns with special reference to high density stands. In: Proceedings of the MCGC Workshop Cocoa Agriculture Research, pp. 153165 .

Ling, A.H., 1986. Litter production and nutrient cycling in a mature cocoa plantation on inland soils of Peninsular Malaysia. In: Pushparajah, E., Chew, P.S. (Eds.), Cocoa and Coconuts: Progress and Outlook. Inc. Society of Planters, Kuala Lumpur, pp. 451-466.

Marcelis, L.F.M., Heuvelink, E., Goudriaan, J., 1998. Modelling biomass production and yield of horticultural crops: a review. Scientia Horticulturae 74, 83-111.

Mialet-Serra, I., Dauzat, J., Auclair, D., 2001. Using plant architectural models for estimation of radiation transfer in a coconut-based agroforestry system. Agrofor. Syst. 53, 141-149.

Miyaji, K.I., da Silva, W.S., Alvim, P.de T., 1997a. Longevity of leaves of a tropical tree Theobroma cacao, grown under shading, in relation to position within the canopy and time of emergence. New Phytol. $138,445-454$.

Miyaji, K.I., da Silva, W.S., Alvim, P.de T., 1997b. Productivity of leaves of a tropical tree Theobroma cacao, grown under shading, in relation to leaf age and light conditions within the canopy. New Phytol. 137, 463-472. 
Mohren, G.M.J., Van Gerwen, C.P., Spitters, C.J.T., 1984. Simulation of primary production in evenaged stands of Douglas fir. For. Ecol. Manage. 9, 27-49.

Müller, M.J., Hennings, D., 2000. Climate 1: the global climate data atlas. CD-ROM. EMTEC Magnetics, Ludwigshafen.

Muñoz, F., Beer, J.W., 2001. Fine root dynamics of shaded cacao plantations in Costa Rica. Agrofor. Syst. 51, 119-130.

Murray, D.B., 1940. Some preliminary studies of transpiration and carbon assimilation in cacao. Trop. Agric. 17, 166-168.

Ng, E.E., 1982. Potential cocoa photosynthetic productivity. In: Proceedings of the 8th International Cocoa Research Conference, pp. 235-244.

Niklas, K.J., Enquist, B.J., 2002. Canonical rules for plant organ biomass partitioning and annual allocation. Am. J. Bot. 89, 812-819.

Okali, D.U.U., Owusu, J.K., 1975. Growth analysis and photosynthetic rates of cocoa (Theobroma cacao L.) seedlings in relation to varying shade and nutrient regimes. Ghana J. Agric. Sci. 8, 51-67.

Opakunle, J.S., 1991. Biomass of a mature cacao (Theobroma cacaoL.) stand in Nigeria. Trop. Ecol. 32, $30-35$.

Penning de Vries, F.W.T., Van Laar, H.H., 1982. Simulation of plant growth and crop production. Simulation monographs. Pudoc, Wageningen.

Radersma, S., De Ridder, N., 1996. Computed evapotranspiration of annual and perennial crops at different temporal and spatial scales using published parameter values. Agric. Water Manage. 31, 17-34.

Raja Harun, R.M., Hardwick, K., 1988. The effect of different temperatures and water vapour pressure deficits on photosynthesis and transpiration of cocoa leaves. In: Proceedings of the 10th International Cocoa Research Conference, pp. 205-209.

Sale, J.P.M., 1968. Flushing and leaf growth of cocoa under controlled temperature conditions. J. Hortic. Sci. 43, 475-489.

Santana, M.B.M., Cabala Rosand, P., 1982. Dynamics of nitrogen in a shaded cacao plantation. Plant Soil 67, 271-281.

Sinclair, T.R., Seligman, N., 2000. Criteria for publishing papers on crop modeling. Field Crops Res. 68, $165-172$.

Somarriba, E., Beer, J., Muschler, R.G., 2001. Research methods for multistrata agroforestry systems with coffee and cacao: recommendations from two decades of research at CATIE. Agrofor. Syst. 53, 195-203.

Subler, S., 1994. Allometric relations for estimating the above-ground biomass of cacao stands in the Eastern Amazon basin. Agrotropica 6, 65-72.

Teoh, K.C., Chan, K.S., Chew, P.S., 1986. Dry matter and nutrient composition in hybrid coconuts (MAWA) and Cocoa on coastal clay soils. In: Pushparajah, E., Chew, P.S (Eds.), Cocoa and Coconuts: Progress and Outlook. Inc. society of planters, Kuala Lumpur, pp. 819-835.

Thong, K.C., Ng, W.L., 1980. Growth and nutrient composition of a monocrop cocoa plants on inland Malaysian soils. In: Proceedings of the International Conference on Cocoa and Coconuts, pp. 262 286.

Valle, R.R., Almeida, A.-A.F., de Leite, R.M.deO., 1990. Energy costs of flowering, fruiting, and cherelle wilt in cacao. Tree Physiol. 6, 329-336.

Van den Berg, M., Driessen, P.M., Rabbinge, R., 2002. Water uptake in crop growth models for land use systems analysis: II. Comparison of three simple approaches. Ecol. Mod. 148, 233-250.

Van Himme, M., 1959. Étude du système radiculaire du cacaoyer. Bull. Agric. Congo Belge et du RuandaUrundi 50, 1542-1600.

Van Ittersum, M.K., Donatelli, M., 2003. Modelling cropping systems - highlights of the symposium and preface to the special issues. Eur. J. Agron. 18, 187-197.

Van Ittersum, M.K., Leffelaar, P.A., Van Keulen, H., Kropff, M.J., Bastiaans, L., Goudriaan, J., 2003. On approaches and applications of the Wageningen crop models. Eur. J. Agron. 18, 201-234.

Van Keulen, H., 1975. Simulation of water use and herbage growth in arid regions. Simulation monographs. Pudoc, Wageningen.

Van Keulen, H., Seligman, N.G., 1987. Simulation of water use, nitrogen nutrition and growth of a spring wheat crop. Simulation Monographs. Pudoc, Wageningen. 
Van Kraalingen, D.G.W., 1989. Simulation of oil palm growth and yield. Agric. For. Meteorol., 227244.

Van Kraalingen, D.G.W., Stol, W., 1997. Evapotranspiration modules for crop growth simulation Implementation of the algorithms from Penman, Makkink and Priestley-Taylor. Quantitative Approaches in Systems Analysis 11. AB-DLO, Wageningen.

Van Laar, H.H., Goudriaan, J., Van Keulen, H., 1992. Simulation of crop growth for potential and water limited production situations (as applied to spring wheat). Simulation reports CABO-TT 27, CABO, Wageningen.

Van Laar, H.H., Goudriaan, J., Van Keulen, H., 1997. SUCROS 97: Simulation of crop growth for potential and water-limited production situations, as applied to spring wheat. Quantitative Approaches in Systems Analysis, vol. 14, AB-DLO, Wageningen.

Veneklaas, E.J., Poorter, L., 1998. Growth and carbon partitioning of tropical tree seedlings in contrasting lightg environments. In: Lambers, H., Poorter, H., Van Vuuren, M.M.I. (Eds.), Variation in Plant Growth. Backhuys Publishers, Leiden, pp. 337-361.

Wagemakers, P.S., 1995. Light relations in orchard systems. PhD thesis. Wageningen University, The Netherlands.

Wallace, J.S., 1996. The water balance of mixed tree-crop systems. In: Ong, C.K., Huxley, P. (Eds.), Treecrop Interactions, A Physiological Approach. CABI, pp. 189-233.

Wessel, M., 1971. Soil aspects of cocoa rehabilitation in Western Nigeria. In: Proceedings of the 11th International Cocoa Conference, pp. 81-85.

Wessel, M., Gerritsma, W., 1994. Re-thinking the shade policy for cocoa growing in West Africa. In: Proceedings of the 11th International Cocoa Research Conference, pp. 681-686.

Wills, G.A., Yegappan, T.M., 1981. Growth of Theobroma cacao L. under conditions of accelerated shade removal. Planter 57, 562-575.

Wolf, J., 2002. Comparison of two potato simulation models under climatic change. I. Model calibration and sensitivity analysis. Clim. Res. 21, 173-186.

Wood, G.A.R., Lass, R.A., 1985. Cocoa, fourth ed. Longman, New York.

Yapp, J.H.H., Hadley, P., 1994. Inter-relationships between canopy architecture, light interception, vigour and yield in cocoa: implications for improving production efficiency. In: Tay, E.B., Lee, M.T., Yap, T.N., Zulkairnain, B.I., Thong, F.T., Bong, S.L., Tee, S.K. (Eds.), Proceedings of the International Cocoa Conference: Challenges in the 90s, pp. 332-350.

Zuidema, P.A., Leffelaar, P.A., 2002a. A physiological production model for cacao: results of model simulations. Department of Plant Sciences, Wageningen University Available from Wageningen University Library: <library.wur.nl>.

Zuidema, P.A., Leffelaar, P.A., 2002b. A physiological production model for cacao: User's manual for CASE2 version2.2 under FSE Windows. Department of Plant Sciences, Wageningen University Available from Wageningen University Library: <library.wur.nl>.

Zuidema, P.A., Leffelaar, P.A., Gerritsma, W., Mommer, L., 2003. A physiological production model for cacao: model description and technical program manual of CASE2 version 2.2. Department of Plant Sciences, Wageningen University Available from Wageningen University Library: <library.wur.nl>. 